REVIEW ARTICLE

\title{
Larvae of gryporhynchid cestodes (Cyclophyllidea) from fish: a review
}

\author{
Tomáš Scholz ${ }^{1,2}$, Rodney A. Bray ${ }^{3}$, Roman Kuchta $^{1,2}$, Radmila Řepová $^{1}$ \\ ${ }^{1}$ Institute of Parasitology, Academy of Sciences of the Czech Republic and ${ }^{2}$ Faculty of Biological Sciences, University of South \\ Bohemia, Branišovská 31, 37005 České Budějovice, Czech Republic; \\ ${ }^{3}$ Department of Zoology, The Natural History Museum, Cromwell Road, London SW7 5BD, UK
}

Key words: Gryporhynchidae, Dilepididae, metacestodes, fish, species composition, host spectrum, distribution, review

\begin{abstract}
Larvae (metacestodes) of tapeworms of the cyclophyllidean family Gryporhynchidae (previously included in the Dilepididae) occur in different internal organs of fresh- and brackish water fish (110 fish species of 27 families in 12 orders reported), which serve as the second intermediate hosts. The species composition, spectrum of fish hosts, sites of infection, and geographical distribution of gryporhynchids recorded from fish are reviewed here on the basis of literary data and examination of extensive material from helminthological collections. Metacestodes of the following genera have been found in fish: Amirthalingamia Bray, 1974 (1 species), Ascodilepis Guildal, 1960 (1), Cyclustera Fuhrmann, 1901 (4), Dendrouterina Fuhrmann, 1912 (1), Glossocercus Chandler, 1935 (3), Neogryporhynchus Baer et Bona, 1960 (1), Paradilepis Hsü, 1935 (5), Parvitaenia Burt, 1940 (2), and Valipora Linton, 1927 (3). However, most published records concern only three species, namely Neogryporhynchus cheilancristrotus (Wedl, 1855) from the intestinal lumen, Paradilepis scolecina (Rudolphi, 1819) from the liver and mesenteries, and Valipora campylancristrota (Wedl, 1855) from the gall bladder of cyprinids and other fish in the Palaearctic Region. Data on other species as well as reports from other regions are very scarce and almost no information is available from Australia, tropical Asia and South America. A recent study of gryporhynchid metacestodes from Mexico (Scholz and Salgado-Maldonado 2001), which reported 13 species, suggested that they may be more common than indicated by records in the literature. Although only a few cases of pathogenic influence of larvae on fish hosts have been reported, the veterinary importance of gryporhynchids remains to be assessed on the basis of more detailed studies. The data available indicate a strict host and site specificity of some species whereas others occur in a wide spectrum of fish hosts and are not strictly site-specific. Evaluation of Paradilepis larvae from the liver of salmonid fish from British Columbia, Canada, identified as P. simoni Rausch, 1949 by Ching (1982), has shown that they probably belong to two species, P. simoni and P. rugovaginosus Freeman, 1954. Metacestodes of the latter species and those of Cyclustera magna (Baer, 1959) from the intestinal wall of Tilapia zillii (Gervais) from Kenya are reported from fish for the first time.
\end{abstract}

\section{INTRODUCTION}

Larval stages (metacestodes) of cestodes previously placed in the Dilepididae (Cyclophyllidea) are parasites of fresh- and brackish water fish (Bona 1975, Chubb 1980, Dubinina 1987). Spassky and Spasskaya (1973) proposed the subfamily Gryporhynchinae to accommodate those species of dilepidids that mature in fisheating birds and have larvae (metacestodes) which occur in fish; Spassky (1995) raised it to family level. Recent phylogenetic studies have confirmed its validity and its distinctness from the Dilepididae sensu stricto (Mariaux 1998, Hoberg et al. 1999, 2001). Therefore, the species previously reported as dilepidids by parasitologists, including the present authors (e.g., Scholz 2001, Scholz and Salgado-Maldonado 2001, Scholz et al. 2002a, b), are considered here to belong to the Gryporhynchidae.

Gryporhynchid metacestodes have been known since the 19th century (see Baer and Bona 1960, and Bona 1975 for a historical overview). However, most data concern only three taxa, namely Neogryporhynchus cheilancristrotus (Wedl, 1855), Paradilepis scolecina (Rudolphi, 1819) and Valipora campylancristrota (Wedl, 1855). In addition, most papers reported only the occurrence of larvae and data on the taxonomy, life cycles, ecology and pathogenic influence of larvae on their fish hosts are scarce.

The shortage of data may be partly related to the fact that gryporhynchid larvae are often overlooked due to their site of infection (mesenteries, liver, etc.). A high number of misidentifications and persistent nomenclatural problems (see Bona 1975) are apparently influenced by the poor quality of available material or its absence in numerous cases. The morphology (number and arrangement, shape and size) of the rostellar hooks represents the basis of species identification (Bona 1975, Scholz and Salgado-Maldonado 2001) but they are often

This paper was presented at the 6th International Symposium on Fish Parasites in Bloemfontein, South Africa, 22-26 September 2003. 
difficult to observe and measure because of inappropriate processing.

Several methods have been proposed to make goodquality preparations to enable adequate morphological and biometrical evaluation, e.g., squashing the scolex, clearing in Berlese's fluid or flattening the worms and their subsequent fixation with glycerin-ammonium picrate according to Malmberg (1957) and Ergens (1969).

In the present paper, a survey of metacestodes of the Gryporhynchidae reported from fish is provided together with data on their fish hosts, sites of infection and geographical distribution. The information is primarily focused on the data published between 1975 and 2003 because Bona (1975) presented a comprehensive overview of records of dilepidid (= gryporhynchid) genera found as larvae in fish. However, some papers published before 1975, especially those from neglected geographical regions, are also included because Bona (1975) reported larvae of only two species, $N$. cheilancristrotus and $V$. campylancristrota.

\section{HOST SPECTRUM}

Fish of numerous families of the following orders (Appendix 1) serve as the second intermediate hosts of gryporhynchids: Acipenseriformes, Atheriniformes, Characiformes, Clupeiformes, Cypriniformes, Cyprinodontiformes, Esociformes, Gasterosteiformes, Perciformes, Salmoniformes, Scorpaeniformes, Siluriformes. Cyprinid fish (Cypriniformes: Cyprinidae) represent the most frequent fish intermediate hosts of metacestodes (45 fish species) but perciform fish, in particular cichlids, harbour the highest number of gryporhynchid species (Appendix 1).

\section{GEOGRAPHICAL DISTRIBUTION}

Most data on gryporhynchid larvae have been accumulated from Europe and countries of the former USSR. However, only three species have been recorded there despite long-term research on fish parasites in this region (e.g., Baer and Bona 1960, Dubinina 1962, 1971, 1987, Molnár 1970, Kozicka 1971, Kennedy 1974, Bona 1975, Ergens et al. 1975, Chubb 1980, Kakacheva-Avramova 1983, Chubb et al. 1987, Priemer and Scholz 1989, Scholz 1989a, Baccarani et al. 1998, Pietrock and Scholz 2000, Moravec 2001). Larvae identified as Gryporhynchus pusillus von Nordmann, 1832 and Neogryporhynchus cheilancristrotus, reported as two valid species by some authors, especially in Russia (e.g., Dubinina 1987), are considered, in accordance with Baer and Bona (1960) and Bona (1975), to be conspecific.

In Canada and USA, the number of records is considerably lower, many of them not being identified to species level, misidentified or unpublished (see Hoffman 1999 for a survey of unpublished findings). Recently, as many as 13 species of gryporhynchid metacestodes have been found in freshwater and brackish water fish in Mexico (Scholz et al. 1996, Scholz and Salgado-Maldonado 2001). This suggests that gryporhynchid larvae may be much more widely distributed in individual regions and continents than indicated by records in the literature. In total, 16 species of gryporhynchid metacestodes have been reported from North America whereas only one ( $V$. campylancristrota) is known from South America.

Gryporhynchid metacestodes have also been reported from freshwater fish, especially tilapias, from Africa, but most have not been identified to species level except for two species (see Taxa of uncertain taxonomic status, doubtful records and synonyms). On the other hand, no species of gryporhynchids has been found in fish from Australia.

\section{LIFE CYCLES}

Data on the biology of gryporhynchids are limited (Beveridge 2001). Jarecka (1970a, b) demonstrated experimentally that the planktonic copepod Eudiaptomus graciloides (Lilljeborg, 1880) served as the first intermediate host of $N$. cheilancristrotus and $V$. campylancristrota (Jarecka 1970a, b) and Mesocyclops oithonoides Sars, 1863 was a suitable intermediate host of $N$. cheilancristrotus. Jarecka (1970a) also infected carp fry, which probably serve as the second intermediate host, with larvae of $V$. campylancristrota from copepods; the larvae (named plerocercus - see Chervy 2002) were located in the gall bladder of carp three days after their experimental infection.

Bauer et al. (1981) presented data of SysolyatinaAndakulova (1979), who also studied the life cycle of $V$. campylancristrota. Copepods such as Arctodiaptomus salinus (Daday, 1885) served as the first intermediate hosts, in the body cavity of which metacestodes ("cercoscolex") became infective after two weeks at 17$25^{\circ} \mathrm{C}\left(20-22\right.$ days at $\left.13-19^{\circ} \mathrm{C}\right)$. After ingestion by the second intermediate host, the metacestode migrated from the intestinal lumen to the gall bladder, where it lay free within its cavity. In the bird definitive host, the parasite matured after 12-15 days, when the first eggs were released. The longevity of the cestode in the definitive host was estimated to be about 9 months (Sysolyatina-Andakulova 1979).

\section{ECOLOGY}

The data on the ecology of gryporhynchid metacestodes from fish are fairly limited. Those on seasonal patterns in the occurrence of gryporhynchid larvae in freshwater fish by 1980 were reviewed by Chubb (1980). The author reported only a few studies on seasonality in the occurrence of gryporhynchid metacestodes, namely that of Neogryporhynchus cheilancristrotus (as Gryporhynchus sp.) in Ukraine (Ivasik 1953), Paradilepis scolecina (as Cysticercus dilepidis) also in Ukraine (Komarova 1957), Valipora campylancristrota (as Cysticercus dilepidis campylancristrotae and Dilepis unilateralis) in Poland (Jara and Olech 
1964a) and Ukraine (Sapozhnikov 1975), respectively, and undetermined species of Dilepididae in Ontario, Canada (Cone and Anderson 1977). More recent data are also very scarce (e.g., Moravec 1983, 1985, 1986, Pietrock and Scholz 2000).

Jara and Olech (1964a) found that carp fry can be infected with metacestodes of $V$. campylancristrota in the first months of their life, as evidenced by the presence of small larvae in their gall bladder. Similarly, Bauer et al. (1981) stated that even 5-7 days old carp were infected with metacestodes. On the other hand, Ivasik (1953) for N. cheilancristrotus and Sapozhnikov (1975) for $V$. campylancristrota reported the infection rate (prevalence and intensity of infection) of small fry to be generally low. Niemczuk and Chorbinski (1996) studied the localisation and activity of some hydrolases in metacestodes of $N$. cheilancristrotus from the intestine of Cyprinus carpio L.

\section{PATHOGENICITY AND VETERINARY IMPORTANCE}

Almost all published data on the pathogenic influence of gryporhynchid larvae concern metacestodes of Valipora campylancristrota from the gall bladder of carp (Cyprinus carpio) and other cyprinids from the former USSR and Poland. The disease, valiporosis, has been considered of veterinary importance in heavily infected fish (Bauer et al. 1981). Pathological changes in the gall bladder and other internal organs appeared only when the worm burden exceeded tens to hundreds of larvae; heavily infected fish were retarded in growth and weight compared with uninfected fish or hosts with low infections (Bauer et al. 1981).

Jara and Olech (1964b) reported a marked congestion and mechanical damage to the blood vessels of carp infected with $V$. campylancristrota but they did not find that this had a negative influence on the condition and weight-gain of parasitized fish.

Körting (1984) reported focal haemorrhages, necrosis and clinical signs of enteritis in the intestines of farmed carp and tench fry infected with gryporhynchid larvae, most probably those of Neogryporhynchus cheilancristrotus, which penetrated deeply into the sub-epithelial layers of the gut.

Suvorov (1981), Studnicka et al. (1984), Nikulina (1985) and Skvortsova et al. (1985) tested treatment of fish infected with metacestodes of $V$. campylancristrota and Nikulina (1985) observed the haematological parameters of carp infected with this cestode.

\section{SURVEY OF SPECIES RECORDED}

To summarise existing data, a list of species of the Gryporhynchidae found as metacestodes in fish is presented here. The list of references provided below is not complete as the most pertinent papers, particularly those summarising previous studies (checklists, monographs), are preferentially cited. Reports from poorly studied areas are also cited, using as a main source the Host-Parasite Data Base from The Natural History Museum, London. Taxa of uncertain taxonomic status and doubtful records are omitted here; they are briefly discussed in the following section.

Besides the review of literary data, available vouchers of gryporhynchid cestodes deposited in helminthological collections have been examined because of the existence of numerous doubtful records and apparent misidentifications. The following specimens have been studied (for a survey of additional extensive material of gryporhynchids from Eurasia and North America previously studied by the present authors see Scholz et al. 1996, 2002a, b, Scholz 2001, Scholz and SalgadoMaldonado 2001):

Harold W. Manter Laboratory of Parasitology, University of Nebraska, Lincoln, USA: Paradilepis simoni Rausch, 1949 - four specimens from the liver of Oncorhynchus nerka (Walbaum) (HWML 38672 and 38673), Oncorhynchus mykiss (Walbaum) (HWML 38674) and Prosopium williamsoni (Girard) (HWML 38676) from British Columbia, Canada.

Institute of Parasitology, Academy of Sciences of the Czech Republic, České Budějovice, Czech Republic (IPCAS): one specimen of Amirthalingamia macracantha (Joyeux et Baer, 1935) from Tilapia zillii (Gervais), Naivasha Lake, Kenya (IPCAS C-292); 5 specimens of Cyclustera magna (Baer, 1959) from the same host and locality (IPCAS C-293), all collected by P.A. Aloo.

U.S. National Parasite Collection, Beltsville, USA: Dendrouterina papillifera (Fuhrmann, 1908) (in fact Valipora minuta (Coil, 1950) - see Scholz and SalgadoMaldonado 2001) - one specimen from the liver of Poecilia sphenops Valenciennes, Mexico (USNPC 88228); Glossocercus cyprinodontis Chandler, 1935 - paratype (USNPC 39528) and 4 vouchers (USNPC 80403) from the body cavity of Cyprinodon variegatus Lacepède, Texas, USA; Paradilepis simoni - paratype (squash of the scolex of an adult cestode) from Pandion haliaetus (L.), Wyoming, USA (USNPC 46403).

In addition, the following specimens of Neogryporhynchus cheilancristrotus from freshwater fish in Japan, collected by Takeshi Shimazu, were studied: (i) from the liver of Gnathopogon caerulescens (Sauvage), Lake Biwa at Moriyama, Shiga Prefecture, 2 May 1992; (ii) from the outer layer (tunica serosa) of the intestine of Zacco platypus (Temminck et Schlegel), Lake Suwa at Suwa, Nagano Prefecture, 21 July 1994; (iii) from the inner layer (mucosa) of the intestine of Carassius auratus langsdorfii Valenciennes in Cuvier et Valenciennes, Hiroi River at Kotobuki, Iiyama, Nagano Prefecture, 12 June 1999; (iv) from the inner layer (mucosa) of the intestine of Misgurnus anguillicaudatus (Cantor), Hiroi River at Kotobuki, Iiyama, Nagano Prefecture, 20 May 2000.

In the lists of fish hosts of individual gryporhynchid species and their geographical distribution (countries), 
records confirmed by the present authors, including those from previous studies on gryporhynchids (see References), are marked with an asterisk. The nomenclature of fish hosts follows that of Froese and Pauly (2003). Scientific names of fish-eating birds are according to del Hoyo et al. (1992).

Amirthalingamia macracantha (Joyeux et Baer, 1935) Bray, 1974

Fig. 1A

Synonyms: Dilepis delachauxi Joyeux et Baer, 1930, nec Fuhrmann, 1909; Paradilepis macracantha Joyeux et Baer, 1935.

F i s h h o s t s : Oreochromis niloticus*, Tilapia zillii* (Perciformes: Cichlidae).

Site of infection: Liver and intestinal wall.

D i stributi o n : Africa: Kenya*, Sudan*.

R e f e r e n c e s : Bray (1974), Aloo (2002 - as Amirthalingamia sp.), present study.

Remarks. The most characteristic feature of the species (and the monotypic genus as well) is the presence of 20 massive hooks of three sizes (up to $480 \mu \mathrm{m}$ in length), arranged in two rows in a bilaterally symmetrical pattern (Bray 1974). Adults have been found in Phalacrocorax africanus (type host) and P. carbo in Africa (Mali, Sudan) (Joyeux and Baer 1935, Bray 1974).

Metacestodes found by Aloo (2002) in the intestinal wall of T. zillii, designated as Amirthalingamia sp., are conspecific with those of $A$. macracantha, as indicated by their morphology, including the arrangement, shape and size (458, 408 and $260 \mu \mathrm{m}$, respectively) of the rostellar hooks (Fig. 1) (see Bray 1974).

\section{Ascodilepis transfuga (Krabbe, 1869) Guildal, 1960}

Fig. 4A

Synonyms: Taenia transfuga Krabbe, 1869; Dilepis transfuga (Krabbe, 1869) Fuhrmann, 1908; Cysticercoides menidiae Chandler, 1935

F i s h h o s t: Menidia menidia* (Atheriniformes: Atherinidae).

$\mathrm{S}$ i t e of in fecti o $\mathrm{n}$ : Intestinal wall, mesenteries.

D i s tri b u ti o n : North America: USA* (Texas).

R e f e r e n c e s : Chandler (1935), Scholz (2001).

Remarks. Metacestodes were originally reported under the name Cysticercoides menidiae by Chandler (1935) but a study of the holotype revealed its conspecificity with Ascodilepis transfuga (see Scholz 2001). Adults of $A$. transfuga have been found in the spoonbill (Platalea ajaja) in Brazil and Venezuela (Díaz-Ungría 1968, Bona 1975).

\section{Cyclustera capito (Rudolphi, 1819) Fuhrmann, 1901}

Synonym: Taenia capito Rudolphi, 1819.

Fig. 2A

F i s h h o s t : Floridichthys polyommus* (Cyprinodontiformes: Cyprinodontidae).

Site of infection: Mesenteries.

D i stributi on : North America: Mexico* (Yucatán).

R e f e r e n c e : Scholz and Salgado-Maldonado (2001).

Remarks. Adults have been found in spoonbills and other fish-eating birds, such as ibises (Platalea ajaja, Eudocimus albus, Mycteria ibis, Plegadis falcinellus, P. leucorodia) from
South and North America (Brazil, Mexico, Cuba, southeastern USA), Africa (Egypt), and ex-USSR (Coil 1955a, Rysavy and Macko 1973, Bona 1975, Sepúlveda et al. 1994, Scholz et al. 2002a).

Cyclustera ibisae (Schmidt et Bush, 1972) Bona, 1975

Synonyms: Parvitaenia ibisae Schmidt et Bush, 1972; P. eudocimi Rysavy et Macko, 1973.

F i s h h o s t s : Fundulus heteroclitus*, F. majalis* (Cyprinodontiformes: Fundulidae).

Site of infection: Mesenteries.

D i s tribution : North America: USA* (South Carolina).

$\mathrm{R}$ e f e r e n c e : Scholz et al. (2002b).

Remarks. The species was described from the white ibis (Eudocimus albus) from Florida by Schmidt and Bush (1972). At almost the same time, Rysavy and Macko (1973), apparently unaware of the paper by the former authors, described conspecific cestodes from the same host and other piscivorous birds (Casmerodius albus, Pelecanus occidentalis, Phalacrocorax auritus, and P. mexicanus) from Cuba (see Bona 1975). Adults of $C$. ibisae have been found in numerous groups of fish-eating birds, but existing records are restricted to southeastern USA (Florida, Georgia), Cuba and southeastern Mexico (Yucatán) - see Scholz et al. (2002b) and references herein.

Cyclustera magna (Baer, 1959) Bona, 1975

Fig. 2C

Synonym: Parvitaenia magna Baer, 1959.

F is h h o s t: Tilapia zillii* (Perciformes: Cichlidae).

$\mathrm{S}$ it e of infection: Intestinal wall.

Distribution: Africa: Kenya*.

R e f e r e n c e : Aloo (2002 - as Cyclustera sp.), present study.

Remarks. Metacestodes collected by Aloo (2002) from the gut wall of Tilapia zillii from Kenya, tentatively identified as Cyclustera sp., are apparently conspecific with adults of $C$. magna. This cestode was described (as Parvitaenia magna) on the basis of one adult cestode from the intestine of Mycteria ibis from Zaire by Baer (1959). According to Bona (1975), who examined the holotype, the rostellar hooks of $C$. magna measure 159-182 $\mu \mathrm{m}$ (larger hooks) and 131-134 $\mu \mathrm{m}$ (smaller hooks) in length. Since the original description, the adult of $C$. magna has not been found (Bona 1975).

Metacestodes from Kenya are 904-1,480 $\mu \mathrm{m}$ long by $496-$ $740 \mu \mathrm{m}$ wide $(\mathrm{n}=5)$; the rostellum has 28 massive hooks in two circles of 14 hooks each; the outer (anterior) circle is composed of two types of hooks of similar shape but different size, 4 hooks being apparently larger (length 179-198 $\mu \mathrm{m}$ ) than the 10 remaining ones $(154-163 \mu \mathrm{m})$. The small hooks have almost straight and narrow blade and are 138-147 $\mu \mathrm{m}$ long. In the presence of two kinds of large hooks, the metacestodes of $C$. magna resemble those of Amirthalingamia macracantha (see above). However, the latter has 10 hooks (4 and 6) in the outer circle instead of 14 (4 and 10) in C. magna.

Cyclustera cf. ralli (Underwood et Dronen, 1986) Bona, 1994

Fig. 2D

F i s h h o s t s: Cyprinus carpio*, Notropis sallei* (Cypriniformes: Cyprinidae); Alloophorus robustus*, Girardinich- 


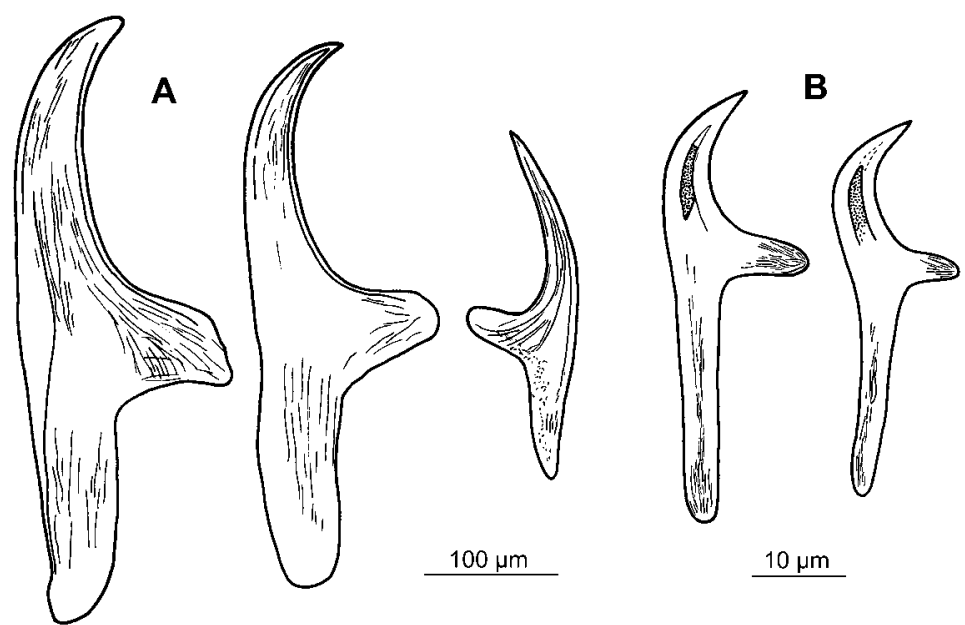

Fig. 1. Rostellar hooks of metacestodes from fish. A - Amirthalingamia macracantha from the intestinal wall of Tilapia zillii, Kenya (IPCAS C-292). B - Dendrouterina pilherodiae from the gall bladder of Rhamdia guatemalensis, Yucatán, Mexico (IPCAS C-241).

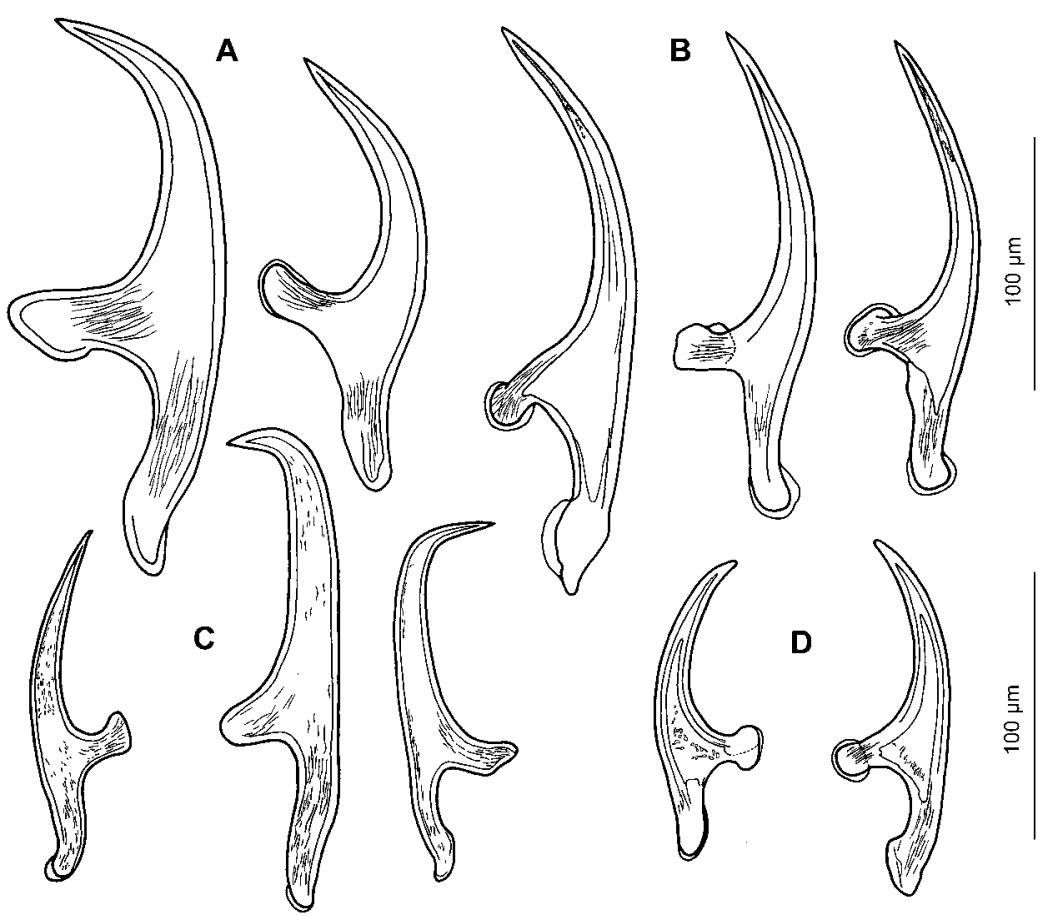

Fig. 2. Rostellar hooks of species of Cyclustera. A - C. capito from the mesenteries of Floridichthys polyommus, Yucatán, Mexico (IPCAS C-279). B - C. ibisae from Fundulus heteroclitus, South Carolina, USA (left and right hooks; IPCAS C-337) and from the intestine of Phalacrocorax olivaceus, Yucatán, Mexico (hook in the middle; IPCAS C-280). C - C. magna from the intestinal wall of Tilapia zillii, Kenya (IPCAS C-293) (note the presence of larger hooks of different shape and size). D - C. cf. ralli from mesenteries of Cyprinus carpio, State of México, Mexico (IPCAS C-312).

thys multiradiatus*, Xenotoca variata* (Cyprinodontiformes: Goodeidae).

Site of infection: Mesenteries.

D i s t r i b u t i o n : North America: Mexico* (Guanajuato, State of México and Michoacán).
R e f e r e n c e : Scholz and Salgado-Maldonado (2001).

Remarks. Metacestodes found in the mesenteries of several species of small cyprinid and goodeid fish from central Mexico resembled in the shape and size of their rostellar hooks those of Cyclustera ralli (syn. Neocyclustera ralli 
Underwood et Dronen, 1986, according to Bona 1994). However, the shape of the hooks of the $C$. ralli paratype (USNPC 78464) and those of metacestodes from Mexico are somewhat different (see Scholz and Salgado-Maldonado 2001). Therefore, the identification of Mexican specimens as Cyclustera cf. ralli is only tentative. It cannot be ruled out that the larvae from Mexican fish belong to a new species of Cyclustera, the adults of which are still unknown.

The type and the only known definitive host of $C$. ralli, which has been reported only from Texas, USA, is the clapper rail Rallus longirostris (see Underwood and Dronen 1986).

\section{Dendrouterina pilherodiae Mahon, 1956}

Fig. 1B

$\mathrm{F}$ is h h o s t: Rhamdia guatemalensis* (Siluriformes: Heptapteridae).

Site of infection: Gall bladder.

D i s tri b u t i o $n$ : North America: Mexico* (Yucatán).

Re fer e n c e : Scholz et al. (1996).

Remarks. The definitive hosts of $D$. pilherodiae are herons, namely Pilherodius pileatus (syn. Nycticorax pileatus) (type host), Egretta alba and Casmerodius albus. Adults have been found in South America (Brazil, Argentina) and southeastern USA (Florida) (Mahon 1956, Bona 1983a, b, Sepúlveda et al. 1999).

Glossocercus cyprinodontis Chandler, 1935

Fig. 3A

$\mathrm{F}$ i s h h o s t: Cyprinodon variegatus* (Cyprinodontiformes: Cyprinodontidae).

Site of infection: Body cavity.

D i s tributi on : North America: USA* (Texas).

R e fer e n c e : Chandler (1935).

Remarks. The type species of Glossocercus Chandler, 1935 is known only as a larval form and its adult form remains unknown (Bona 1994, Pichelin et al. 1998). Metacestodes have never been found since the original description by Chandler (1935).

\section{Glossocercus auritus (Rudolphi, 1819) Bona, 1994}

Synonyms: Taenia aurita Rudolphi, 1819; Parvitaenia aurita (Rudolphi, 1819) Baer et Bona, 1960; Anomotaenia aurita (Rudolphi, 1819) Fuhrmann, 1908.

F i s h h o s t s : Astyanax fasciatus (Characiformes: Characidae); Poecilia catemaconis*, P. mexicana*, P. sphenops*,

Poecilia sp.*, Poeciliopsis gracilis* (Cyprinodontiformes: Poeciliidae).

$\mathrm{S}$ it e of infection: Liver, mesenteries, intestinal wall.

D i s t r i b u t i o n : North America: Mexico* (Guerrero, Hidalgo, Oaxaca, Veracruz).

R e f e r e n c e s : Salgado-Maldonado et al. (2001), Scholz and Salgado-Maldonado (2001).

Remarks. This cestode seems to be a specific parasite of herons of the genera Egretta and Casmerodius and has been found only in Brazil, Cuba, Nicaragua and Neotropical Mexico (Veracruz) (Schmidt and Neiland 1971, Rysavy and Macko 1973, Bona 1975, Scholz et al. 2002a).
Glossocercus caribaensis (Rysavy et Macko, 1973) Bona, 1994

Fig. 3C

Synonyms: Parvitaenia caribaensis Rysavy et Macko, 1973; P. heardi Schmidt et Courtney, 1973.

$\mathrm{F}$ is h h o s t s : Fundulus grandissimus*, F. heteroclitus*, $F$. majalis*, $F$. persimilis* (Cyprinodontiformes: Fundulidae); Cichlasoma urophthalmus* (Perciformes: Cichlidae).

$\mathrm{S}$ it e of infection: Mesenteries and liver.

D i s t r i b u t i o n : North America: Mexico (Yucatán), USA (South Carolina, Texas).

$\mathrm{R}$ e f e r e n c e s : Chandler (1935) (as Glossocercus cyprinodontis - see remarks), Scholz and Salgado-Maldonado (2001), Scholz et al. (2002b).

Remarks. The cestode was originally described from the intestine of the herons Ardea herodias and Casmerodius albus in Cuba and then found also in southeastern USA (Florida, South Carolina) (Rysavy and Macko 1973, Schmidt and Courtney 1973 - as Parvitaenia heardi, Sepúlveda et al. 1999). Chandler (1935) misidentified one specimen of $G$. caribaensis from the mesenteries of Fundulus heteroclitus (USNPC 80404) as Glossocercus cyprinodontis (see Scholz and Salgado-Maldonado 2001).

With the exception of two specimens found (? accidentally) in the cichlid Cichlasoma urophthalmus, which may live also in brackish water (Vidal-Martínez et al. 2001), fish of the genus Fundulus are exclusive second intermediate hosts of the parasite. Metacestodes of G. caribaensis have not been found in other cyprinodontid fish (Cyprinodon, Floridichthys) living sympatrically in brackish waters in southeastern USA and Mexico.

Neogryporhynchus cheilancristrotus (Wedl, 1855) Baer et Bona, 1960 Fig. 7A

Synonyms: Taenia cheilancristrota Wedl, 1855; ? Gryporhynchus pusillus von Nordmann, 1832; G. cheilancristrotus (Wedl, 1855) Fuhrmann, 1907; G. tetrorchis Hill, 1941; Gryporhynchus sp. Kozicka, 1959; Cysticercus gryporhynchispusillae Joyeux et Baer, 1936; C. gryporhynchis-cheilancristroti Joyeux et Baer, 1936 (for complete list of synonyms, see Baer and Bona 1960, and Bona 1975).

$\mathrm{F}$ i s h h o s t s : primarily cypriniform fish, such as Abramis brama, A. ballerus*, A. sapa, Alburnoides taeniatus, Alburnus alburnus, Aspiolucius esocinus, Aspius aspius, Barbus brachycephalus, B. capito, Blicca bjoerkna*, Capoeta capoeta, Capoetobrama kuschakewitschi, Carassius auratus*, C. carassius*, Chalcalburnus chalcoides, Ctenopharyngodon idella, Cyprinus carpio*, Gnathopogon caerulescens*, Hemiculter eigenmanni, Leucaspius delineatus, Leuciscus cephalus*, L. idus, L. lehmanni, Pelecus cultratus, Rhodeus sericeus, Rutilus rutilus*, Scardinius erythrophthalmus, Schizothorax intermedius, Tinca tinca*, Zacco platypus* (Cypriniformes: Cyprinidae); Cobitis taenia, Misgurnus anguillicaudatus*, M. fossilis* (Cypriniformes: Cobitidae). Other fish may also serve as second intermediate hosts, e.g., Pseudoscaphirhynchus kaufmanni (Acipenseriformes: Acipenseridae); Alosa kessleri (Clupeiformes: Clupeidae); Esox lucius (Esociformes: Esocidae); Gymnocephalus cernuus, Perca fluviatilis, P. schrenkii, Zingel streber (Perciformes: Percidae); Channa argus* (Perciformes: Channidae); Liza abu (Perciformes: Mugilidae); Silurus asotus, S. glanis (Siluriformes: Siluridae). 


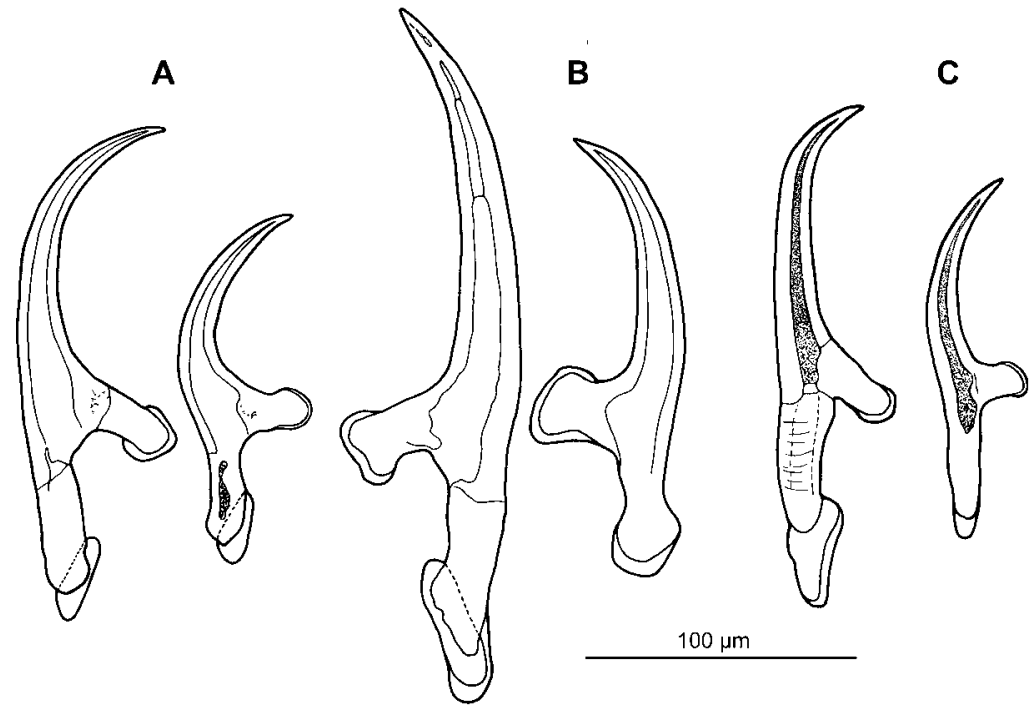

Fig. 3. Rostellar hooks of metacestodes of Glossocercus. A - G. cyprinodontis from the body cavity of Cyprinodon variegatus, Texas, USA (USNPC 80403). B - G. auritus from the mesenteries of Poecilia catemaconis (large hook) and Poeciliopsis gracilis (small hook), Veracruz and Guerrero, Mexico (IPCAS C-281). C - G. caribaensis from Fundulus heteroclitus, South Carolina, USA (IPCAS C-282).
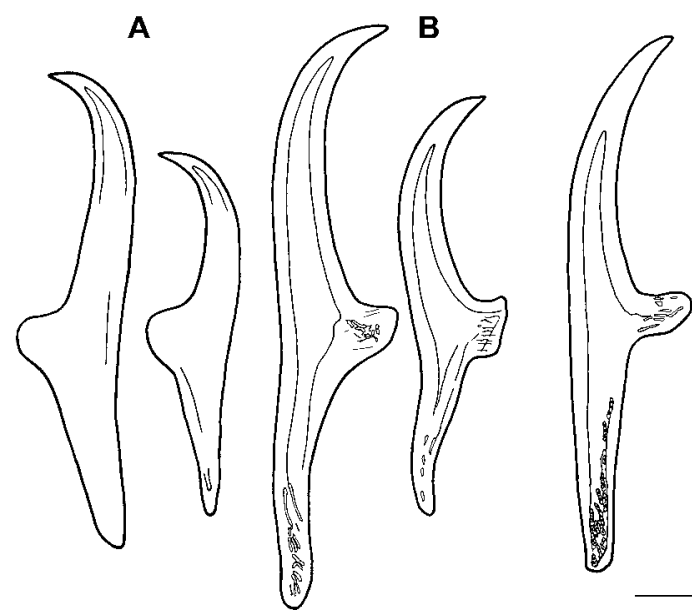

C

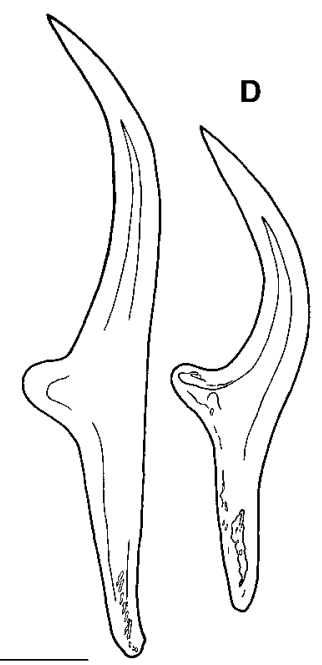

Fig. 4. Rostellar hooks of metacestodes of Ascodilepis and Paradilepis. A - A. transfuga from the intestinal wall and mesenteries of Menidia menidia from Texas, USA (USNPC 39530). B - P. caballeroi from the liver of Chirostoma jordani, Guanajuato, Mexico (IPCAS C-313). C - P. scolecina from mesenteries of Rutilus rutilus, Czech Republic (IPCAS C-127). D - P. cf. urceus from the liver of Chirostoma jordani, Guanajuato, Mexico (IPCAS C-315).

Site of infection: Intestine (lumen).

D i s t r i b u t i o n : Europe: Belorussia, Bulgaria, Czech Republic*, Germany*, Hungary, Italy, Lithuania, Moldavia, Poland, Romania, Russia, Slovakia*, Ukraine; Asia: Azerbaidzhan, Georgia, Iraq, Japan*, Kazakhstan, Tadjikistan, Turkmenia, Uzbekistan.

R e f e r e n c e s : Baer and Bona (1960), Kozicka (1971), Bona (1975), Ergens et al. (1975), Pastuszko et al. (1984), Ali et al. (1987a), Dubinina (1987), Grabda-Kazubska et al. (1987), Scholz (1989a), Pojmańska (1991), Baccarani et al. (1998), Hanzelová and Ryšavý (1999), Pietrock and Scholz (2000), Kirin (2001), Moravec (2001), Popiolek (2002), present study (specimens from Japan). As Gryporhynchus cheilancristrotus - Bogdanova (1961), Esinenko-Marits (1965), Kulakovskaya (1969), Dubinina (1971), Osmanov (1971), Astachova and Stepanova (1972), Kulakovskaya and Koval (1973), Skryabina (1974), Margaritov (1976), Izyumova (1977), Andakoulova (1978), Adamczyk (1979), Kurashvili et al. (1980), Kakacheva-Avramova (1983), Rautskis (1988), Gavrilova and Karimov (1989), Naimova and Roitman (1989), Margaritov (1992); as Gryporhynchus pusillus - Iskov (1965), Kulakovskaya (1969), Osmanov (1971), Skryabina (1974), Kurashvili et al. (1980), Dubinina (1987), Ibragimov (1988), Gavrilova and Karimov 
(1989), Razmashkin (1990), Ermolenko and Butorina (1998), Boutorina and Ermolenko (2001); as Gryporhynchus sp. - Molnár (1970); as Dilepididae gen. sp. 2 - Shimazu et al. (2000).

Remarks. The complicated taxonomic history of this species was reviewed in detail by Baer and Bona (1960) and Bona (1975). The former authors proposed a new genus, Neogryporhynchus, to accommodate Wedl's species Taenia cheilancristrota because of impossibility to identify Gryporhynchus pusillus von Nordmann, 1832.

In this study, metacestodes of $N$. cheilancristrotus are reported from Japan for the first time. However, conspecific larvae, which had been reported as Dilepididae gen. sp. 2 (see below) by Shimazu et al. (2000), have also been found to belong to this species.

Jarecka (1970b) proved experimentally that the copepod Mesocyclops oithonoides served as the first intermediate host. Adults of $N$. cheilancristrotus are intestinal parasites of herons, such as Ardea cinerea, A. herodias, A. purpurea, Botaurus stellaris (type host), and Nycticorax nycticorax (Bona 1975).

\section{Paradilepis caballeroi Rysavy et Macko, 1973}

Fig. 4B

F i s h ho s t s : Chirostoma jordani* (Atheriniformes: Atherinidae); Cichlasoma callolepis* (Perciformes: Cichlidae).

$\mathrm{S}$ it e of infection: Mesenteries and liver.

D i s t r i b u t i o n : North America: Mexico* (Campeche, Guanajuato).

R e f e r e n c e : Scholz and Salgado-Maldonado (2001).

Remarks. Adults are specific parasites of cormorants (Phalacrocorax auritus, P. brasilianus and P. olivaceus) found only in Cuba, Neotropical Mexico (Veracruz) and USA (Rysavy and Macko 1973, Fedynich et al. 1997, Scholz et al. 2002a). Scholz et al. (2002a) discussed the validity of the species which differs from $P$. scolecina (Rudolphi, 1819), a common parasite of cormorants in Eurasia, Africa and Australia (Ryzhikov et al. 1985), only in the higher number of rostellar hooks (12 in one row, i.e. 24 in total, versus $10+10$ $=20$ in P. scolecina).

\section{Paradilepis scolecina (Rudolphi, 1819)}

Fig. 4C

Synonyms: Taenia scolecina Rudolphi; Dilepis scolecina (Rudolphi, 1819) Fuhrmann, 1908; Cysticercus dilepidis Dogiel et Bychowsky, 1934; Paradilepis duboisi Hsü, 1935; P. brevis Burt, 1940.

$\mathrm{F}$ i s h h o s t s: The most common hosts are cyprinids, e.g., Abramis brama, A. sapa, Alburnus albidus, A. alburnus, Aristichthys nobilis*, Aspius aspius, Barbus brachycephalus, B. capito, Blicca bjoerkna*, Capoeta capoeta, Carassius auratus, C. carassius*, Chalcalburnus chalcoides, Chondrostoma cyri, C. nasus, Culter alburnus, Cyprinus carpio*, Gnathopogon elongatus, Hemiculter leucisculus, Leuciscus idus, Oreoleuciscus humilis*, O. potanini*, Pelecus cultratus, Rhodeus sericeus, Rutilus rutilus*, Scardinius erythrophthalmus*, Schizopygopsis stoliczkae, Tinca tinca, Tribolodon hakonensis*, Varicorhinus sp. (Cypriniformes: Cyprinidae); Acipenser nudiventris, Pseudoscaphirhynchus kaufmanni (Acipenseriformes: Acipenseridae); Esox lucius (Esociformes: Esocidae); Gasterosteus aculeatus, Pungitius pungitius, P. platygaster (Gasterosteiformes: Gasterosteidae); Gymnocephalus cernuus, Perca fluviatilis (Perciformes: Percidae); Neogobius melanostomus (Perciformes: Gobiidae); Silurus glanis (Siluriformes: Siluridae).

Site of infection: Mesenteries and liver.

D i s t r i b u t i o n : Europe: Bosnia and Hercegovina, Bulgaria, Czech Republic*, Germany*, Greece, Hungary, Italy, Lithuania, Poland*, Romania, Russia, Ukraine, Yugoslavia (Monte Negro); Asia: Azerbaidzhan, Georgia, Japan*, Kazakhstan, Mongolia*, Tadjikistan, Uzbekistan.

R e f e r e n c e s : Yamaguti (1940), Dubinin (1952), Dubinina $(1962,1971,1987)$, Kulakovskaya $(1965,1969)$, Kažić (1970), Molnár (1970), Kozicka (1971), Osmanov (1971), Kulakovskaya and Koval (1973), Skryabina (1974), Mikailov (1975), Margaritov (1976), Izyumova (1977), Knezević et al. (1978), Kurashvili et al. (1980), Mikailov and Ibragimov (1980), Kazieva (1981), Kiskaroly et al. (1981), Kakacheva-Avramova (1983), Dzhalilov (1985), Ryzhikov et al. (1985), Grabda-Kazubska et al. (1987), Dupont and Crivelli (1988), Rautskis (1988), Priemer and Scholz (1989), Scholz (1989b), Kazieva and Mikailov (1990), Scholz and Ergens (1990), Pojmańska (1991), Margaritov (1992), Molnár and Székely (1996), Murai et al. (1997), Baccarani et al. (1998), Grupcheva and Nedeva (1999), Rolbiecki et al. (1999), Boutorina and Ermolenko (2001), Kalbe et al. (2002), present study (specimens from the Czech Republic and Japan).

Remarks. Although adults are frequent and widely distributed parasites of cormorants in Europe, Asia, Africa and Australia (Matevosyan 1963, Ryzhikov et al. 1985, Schmidt 1986), metacestodes in fish are known from Eurasia only. The pathological effect of adults of $P$. scolecina on its definitive host, the white-necked cormorant (Phalacrocorax carbo), was studied by Karstad et al. (1982). The copepod Eudiaptomus graciloides is the first intermediate host under experimental conditions (Jarecka 1970b).

\section{Paradilepis simoni Rausch, 1949}

Figs. 5, 6A, B

F i s h h o s t s : Oncorhynchus nerka (Salmoniformes: Salmonidae) (voucher HWML 38673); ? Ptychocheilus oregonensis (Cypriniformes: Cyprinidae); ? Cottus asper (Scorpaeniformes: Cottidae) (see Remarks).

Site of infection: Liver.

$\mathrm{D}$ i s t r i b u t i o $\mathrm{n}$ : North America: Canada (British Columbia).

R e f e r e n c e : Ching (1982).

Remarks. Ching (1982) identified metacestodes found in salmonids from British Columbia, Canada, as $P$. simoni on the basis of the number of rostellar hooks (30-36 according to her observations) and their shape (proportion of the handle and blade). Paradilepis simoni was described from the intestine of Haliaetus carolinensis in the USA (Rausch 1949) and then redescribed by McLaughlin (1974). In the original description, a total of about 36 hooks was reported (Rausch 1949) but the paratype (squash of the scolex; USNPC 46403) has only 28 hooks in two rows of 14 hooks each (Figs. 5, 6A).

A study of Ching's specimens has revealed that one larva from Oncorhynchus nerka (HWML 38673) possesses only 28 hooks (14 larger hooks 103-104 $\mu \mathrm{m}$ long and 14 smaller hooks 70-76 $\mu \mathrm{m}-$ Fig. 6B) whereas another larva from the same fish host (HWML 38672 - Fig. 6C) as well as those from O. mykiss (HWML 38674 - Fig. 6D) and Prosopium williamsoni (HWML 38676 - Fig. 6E) have 32 hooks arranged in two circles of 16 each. The hooks of the former metacestode 


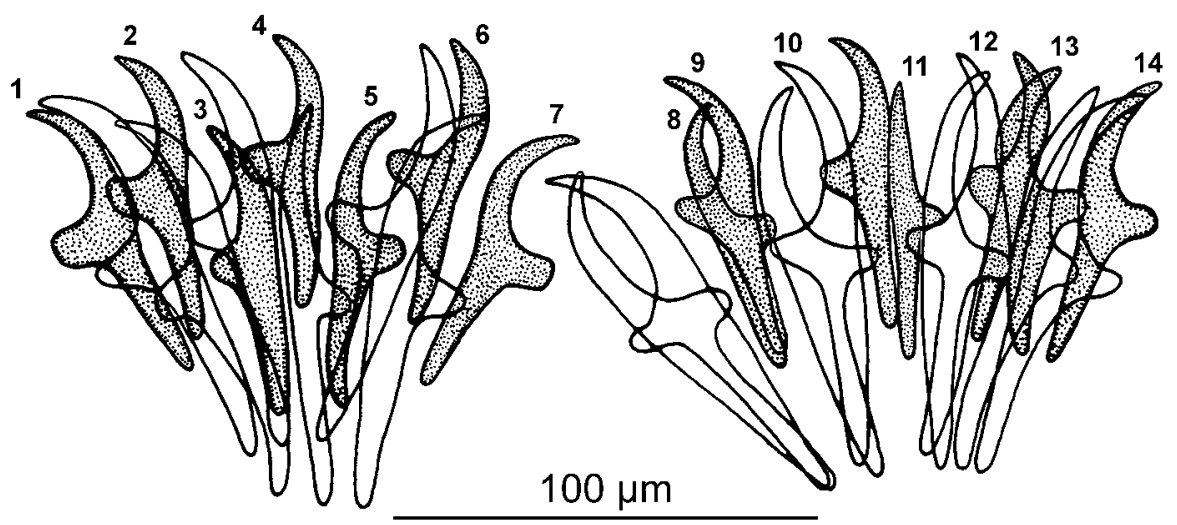

Fig. 5. Rostellar hooks of Paradilepis simoni adult (paratype) from the intestine of Pandion haliaetus, Wyoming, USA (USNPC 46403). Note presence of 28 hooks $(14+14)$.

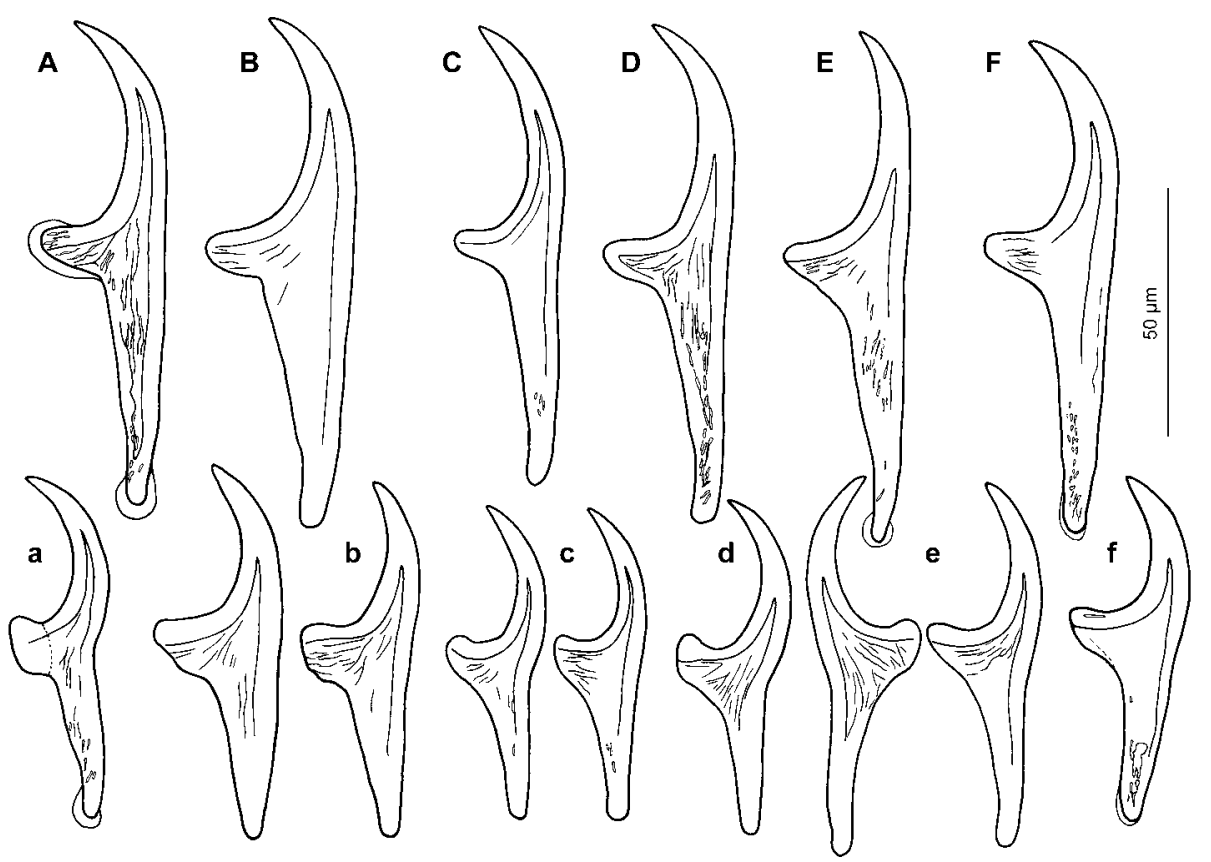

Fig. 6. Large (capital letters) and small (lowercase letters) rostellar hooks of species of Paradilepis. A, B - P. simoni. A - adult (paratype) from the intestine of Pandion haliaetus, Wyoming, USA (USNPC 46403); B - metacestode from the liver of Oncorhynchus nerka, British Columbia, Canada (HWML 38673). C-E - Metacestodes of P. rugovaginosus from the liver of Oncorhynchus nerka (C) (HWML 38672), O. mykiss (D) (HWML 38674) and Prosopium williamsoni (E) (HWML 38676), British Columbia, Canada. F - Paradilepis sp. from the liver of Chirostoma jordani, Guanajuato, Mexico (IPCAS C-314).

(HWML 38673) are also slightly more robust, in particular larger ones (Fig. 6B).

The different number of hooks and slight difference in their shape indicate that the larvae found by Ching (1982) belong to two different species of Paradilepis Hsü, 1935, most probably $P$. simoni (larva from $O$. nerka with 28 hooks - HWML 38673) and P. rugovaginosus Freeman, 1954 (metacestodes with 32 hooks - HWML 38672, 38674, 38676).

Species identification of metacestodes from Ptychocheilus coregonensis and Cottus asper could not be confirmed because voucher specimens were not available.
Paradilepis rugovaginosus Freeman, 1954

Fig. 5C-E

F i s h h o s t s : Oncorhynchus mykiss, O. nerka, Prosopium williamsoni (Salmoniformes: Salmonidae).

Site of infection: Liver.

$\mathrm{D}$ i s t r i b u t i o $\mathrm{n}$ : North America: Canada (British Columbia).

R e f e r e n c e : Ching (1982 - as $P$. simoni), present study.

Remarks. Metacestodes from Oncorhynchus nerka (HWML 38672), O. mykiss (HWML 38674) and Prosopium williamsoni (HWML 38676), all possessing 32 hooks arranged 
in two circles of 16 each, are considered to be conspecific with $P$. rugovaginosus described by Freeman (1954) from the osprey, Pandion haliaetus, from Ontario, Canada. Freeman (1954) reported adult tapeworms to possess 32 rostellar hooks 99-103 $\mu \mathrm{m}$ (larger hooks) and 70-72 $\mu \mathrm{m}$ (smaller hooks) long, respectively. This corresponds well with measurements of the hooks of metacestodes (93-108 $\mu \mathrm{m}$ and $67-76 \mu \mathrm{m}$; present data, Table 1), which further supports the assumption that these larvae are conspecific with Paradilepis rugovaginosus.

\section{Paradilepis cf. urceus (Wedl, 1855) Joyeux et Baer, 1950}

Synonym: Taenia urceus Wedl, 1855

Fig. 4D

$\mathrm{F}$ i s h h o s t: Chirostoma jordani* (Atheriniformes: Atherinidae).

Site of infection: Liver.

D i s tribut i o n : North America: Mexico* (Guanajuato).

R e f e r e n c e : Scholz and Salgado-Maldonado (2001).

Remarks. Metacestodes from the liver of an atherinid fish in Mexico closely resembled in their hook morphology the adults of $P$. urceus, a parasite of Plegadis falcinellus, Platalea leucorodia, and Milvus migrans recorded from Europe, Africa (Egypt) and Asia (India) (Bona 1975). However, there was a marked difference in the position of the guard in the large hooks, i.e. in the blade/handle ratio: 1.06-1.33 in metacestodes (Scholz and Salgado-Maldonado 2001) versus 1.50 in adults (Bona 1975).

\section{Parvitaenia cochlearii Coil, 1955}

Fig. 7B

$\mathrm{F}$ i s h h o s t s : Atherinella crystallina* (Atheriniformes: Atherinidae); Poeciliopsis gracilis* (Cyprinodontiformes: Poeciliidae); Dormitator latifrons*, Gobiomorus maculatus* (Perciformes: Eleotridae); Agonostomus monticola* (Perciformes: Mugilidae).

Site of infection: Liver.

D i s t r i b u t i o n : North America: Mexico* (Guerrero, Jalisco, Nayarit).

R e f e r e n c e : Scholz and Salgado-Maldonado (2001).

Remarks. The spectrum of fish hosts of $P$. cochlearii is fairly wide and includes members of four families. This contrasts with the fact that adult cestodes have been found only once in the boat-billed heron Cochlearius cochlearius from Mexico (Coil 1955b).

\section{Parvitaenia macropeos (Wedl, 1855) Baer et Bona, 1960}

Synonyms: Taenia macropeos Wedl, 1855; Anomotaenia macropeos (Wedl, 1855) Fuhrmann, 1908; Parvitaenia echinatia Metrick, 1967; Gryporhynchus pusillus auctorum (see Baer and Bona 1960, p. 92), nec von Nordmann, 1832. F i s h h o st: Cichlasoma istlanum (Perciformes: Cichlidae). Site of infection: Liver.

$\mathrm{D}$ i s t r i b u t i o n : North America: Mexico (Guerrero).

R e f e r e n c e s : Scholz and Salgado-Maldonado (2001).

Remarks. The cestode is a specific parasite of Nycticorax nycticorax occurring in Europe (Hungary, Italy), Asia (Japan, Java, Sri Lanka, Taiwan) and Africa (Zambia) (Bona 1975, Jensen et al. 1983). Metacestodes are known only from central Mexico (Scholz and Salgado-Maldonado 2001).
Valipora campylancristrota (Wedl, 1855) Baer et Bona, 1960

Fig. 7D, E

Synonyms: Taenia campylancristrota Wedl, 1855; Gryporhynchus pusillus Aubert, 1857; Dilepis unilateralis Clerc, 1906 nec Rudolphi, 1819; D. campylancristrota (Wedl, 1855) Fuhrmann, 1908; Cysticercus dilepis-campylancristrotae Joyeux et Baer, 1936.

$\mathrm{F}$ i s h h o s t s : primarily cyprinid fish (Cypriniformes: Cyprinidae), such as Abramis brama, Alburnoides taeniatus, Alburnus alburnus, Aristichthys nobilis, Aspius aspius, Barbus brachycephalus, B. capito, Carassius auratus*, C. carassius*, Chalcarburnus chalcoides, Ctenopharyngodon idella*, Cyprinus carpio*, Hemiculter eigenmanni, Hypophthalmichthys molitrix, Leuciscus cephalus, Leucaspius delineatus, Pelecus cultratus, Rhodeus sericeus, Rutilus rutilus, Scardinius erythrophthalmus, Schizothorax intermedius, Tinca tinca* (most common host).

Numerous fish of other families have also been reported as second intermediate hosts, e.g., Acipenser nudiventris, $A$. stellatus, Pseudoscaphirhynchus kaufmanni (Acipenseriformes: Acipenseridae); Chirostoma humboldtianum*, C. jordani*, C. riojai* (Atheriniformes: Atherinidae); Prochilodus lineatus (Characiformes: Prochilodontidae); Alosa caspia (Clupeiformes: Clupeidae); Girardinichthys multiradiatus* (Cyprinodontiformes: Goodeidae); Esox lucius (Esociformes: Esocidae); Gasterosteus aculeatus (Gasterosteiformes: Gasterosteidae); Perca fluviatilis, Sander lucioperca (Perciformes: Percidae); Salaria fluviatilis (Perciformes: Blenniidae); Silurus glanis (Siluriformes: Siluridae); Mystus halepensis (= Mystus pelusius) (Siluriformes: Bagridae); Rhamdia guatemalensis* (Siluriformes: Heptapteridae).

$\mathrm{S}$ i t e of i n f e c t i o $\mathrm{n}$ : Gall bladder (records from the intestine are considered to be doubtful).

D i s t r i b u t i o n : Europe: Czech Republic*, Germany*, Hungary, Italy, Latvia, Lithuania, Moldavia, Poland, Romania, Russia, Slovakia*, Ukraine, Yugoslavia (Monte Negro); Asia: Iraq, Japan, Kazakhstan, Mongolia*, Tadjikistan, Uzbekistan; North America: Canada, Mexico*; South America: Brazil.

R e f e r e n c e s : Jarecka (1970a), Kozicka (1971), Skvortsova (1979), Bauer et al. (1981), Razmashkin (1984), Studnicka et al. (1984), Ryzhikov et al. (1985), Ali et al. (1987b, 1988), Dubinina (1987), Scholz (1989a), Priemer and Scholz (1989), Razmashkin (1990), Scholz and Ergens (1990), Pojmańska (1991), Takemoto et al. (1994), Mhaisen and Khamees (1995), Kirichenko (1996), Baccarani et al. (1998), Ermolenko and Butorina (1998), Hanzelová and Ryšavý (1999), Rego et al. (1999), Moravec (2001), Scholz and Salgado-Maldonado (2001), Kalbe et al. (2002). As Cysticercus dilepidis - Agapova (1960); as Dilepididae gen. sp. 1 - Shimazu et al. (2000); as Dilepis campylancristrota - Jara and Olech (1964a, b); as Dilepis unilateralis Golikova (1960), Esinenko-Marits (1965), Molnár (1970), Osmanov (1971), Molnár et al. (1974), Skryabina (1974), Izyumova (1977), Adamczyk (1979), Grabda-Kazubska et al. (1987), Chernova et al. (1988), Gavrilova and Karimov (1989); as Ophiovalipora unilateralis - Kulakovskaya (1969), Kulakovskaya and Koval (1973); as Valipora unilateralis - Rautskis (1988).

Remarks. Herons, e.g., Ardea cinerea (type host), serve as the definitive hosts of the cestode, the adults of which have 


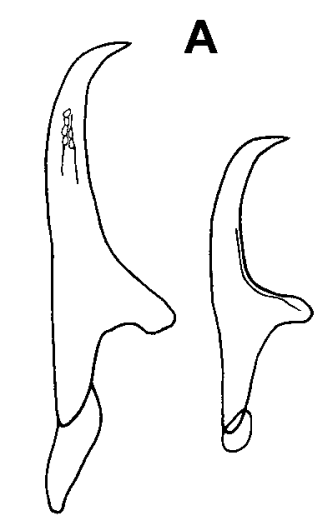

B

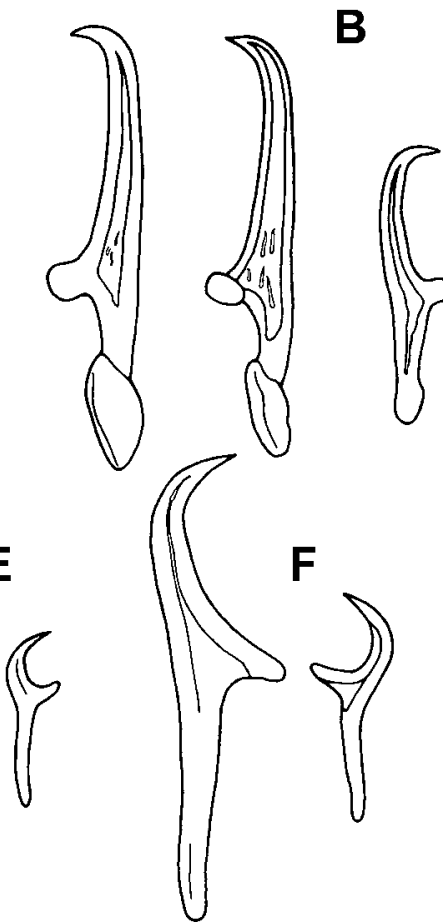

C

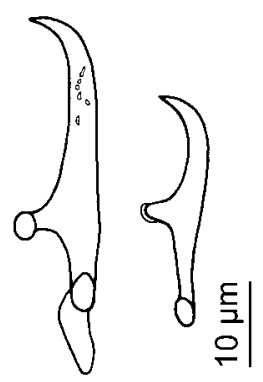

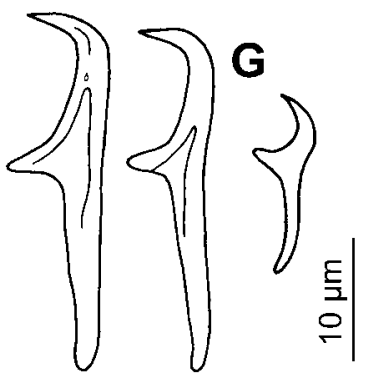

Fig. 7. Rostellar hooks of metacestodes of Neogryporhynchus from the intestinal lumen, Parvitaenia from the liver and Valipora from the gall bladder. A - N. cheilancristrotus from Channa argus, Japan (IPCAS C-39). B - P. cochlearii from Gobiomorus maculatus, Jalisco, Mexico (IPCAS C-254). C - P. macropeos from Cichlasoma istlanum, Guerrero, Mexico (IPCAS C-283). D - V. campylancristrota from Cyprinus carpio, Czech Republic (IPCAS C-27). E - V. campylancristrota from Rhamdia guatemalensis, Yucatán, Mexico (large hook) and Chirostoma jordani, State of México, Mexico (small hook). F - V. minuta from Rhamdia guatemalensis, Yucatán, Mexico (large hook) and Poeciliopsis gracilis, Guerrero, Mexico (small hook) (IPCAS C240). G - V. mutabilis from Cichlasoma beani, Nayarit, Mexico (left large hook and small hook) and C. meeki, Campeche, Mexico (right large hook) (IPCAS C-302).

been found only in Europe (Hungary, Italy, Moldavia and Russia - Ural) (Baer and Bona 1960, Spasskaya et al. 1974, Ryzhikov et al. 1985), which contrasts with wide distribution of metacestodes reported from Europe, Asia and North and South America.

Jarecka (1970a) demonstrated experimentally that the copepod Eudiaptomus graciloides is a suitable first intermediate host for $V$. campylancristrota. Data on development in the copepod Arctodiaptomus salinus, were also provided by Sysolyatina-Andakulova (1979).

\section{Valipora minuta (Coil, 1950) Baer et Bona, $1960 \quad$ Fig. 7F}

Synonym: Ophiovalipora minuta Coil, 1950

F i s h h o s t s : Poecilia sphenops* (Cyprinodontiformes: Poeciliidae); Rhamdia guatemalensis* (Siluriformes: Heptapteridae); Gambusia affinis (Cyprinodontiformes: Poeciliidae); Micropterus punctatus, M. salmoides (Perciformes: Centrarchidae).

Site of infection: Gall bladder.

D i s t r i b u t i o n : North America: Mexico* (Guerrero, Quintana Roo, Yucatán), USA (Arkansas, Texas).

R e f e r e n c e s : Davis and Huffman (1975 - as Ophiovalipora minuta), Scholz et al. (1996 - as Dendrouterina papillifera), W. Evans (unpublished data - see Hoffman 1999), Scholz and Salgado-Maldonado (2001).

Remarks. Adults have been found in the intestine of Butorides virescens in the USA (Coil 1950).

Valipora mutabilis Linton, 1927

Fig. 7B

Synonyms: Ophiovalipora houdemeri Hsü, 1935; O. nycticoracis (Olsen, 1937) Coil, 1950; Dendrouterina lintoni Olsen, 1937; D. nycticoracis Olsen, 1937.

$\mathrm{F}$ i s h h o s t s : Rhamdia guatemalensis (Siluriformes: Heptapteridae); Ameiurus melas (= Ictalurus melas) (Siluriformes: Ictaluridae); Cichlasoma beani, C. geddesi, Thorichthys meeki (Perciformes: Cichlidae).

S it e of infection: Gall bladder.

$\mathrm{D}$ i s t r i b u t i o n : North America: Mexico (Campeche, Nayarit, Yucatán), USA

R e f e r e n c e : Olsen (1939 - as Dendrouterina nycticoracis), Scholz and Salgado-Maldonado (2001).

Remarks. Herons (Butorides virescens, Nycticorax nycticorax) serve as the definitive hosts of $V$. mutabilis that has been found in North America (Cuba, Mexico, USA), Europe (Italy) and Asia (China) (Coil 1950, Rysavy and Macko 1973, Bona 1975, Scholz et al. 2002a). Metacestodes are known only from Mexico (Scholz and Salgado-Maldonado 2001). 
Table 1. Measurements (in $\mu \mathrm{m}$ ) of rostellar hooks of gryporhynchid metacestodes from fish.

\begin{tabular}{|c|c|c|c|c|c|c|c|c|c|c|}
\hline \multirow{2}{*}{ Species } & \multirow{2}{*}{ Number } & \multicolumn{4}{|c|}{ Large hooks } & \multicolumn{4}{|c|}{ Small hooks } & \multirow{2}{*}{ Source } \\
\hline & & Length & Blade & Handle & $\mathrm{B} / \mathrm{H}$ ratio & Length & Blade & Handle & $\mathrm{B} / \mathrm{H}$ ratio & \\
\hline Amirthalingamia macracantha & $(4+6)+10$ & $\begin{array}{l}448-480 \\
390-450\end{array}$ & $\begin{array}{l}272-296 \\
140-280\end{array}$ & $\begin{array}{l}240-296 \\
224-256\end{array}$ & $\begin{array}{l}1.00-1.16 \\
1.00-1.18\end{array}$ & $240-290$ & $157-184$ & $144-160$ & $0.98-1.11$ & $1, \mathrm{PD}$ \\
\hline Ascodilepis transfuga & $10+10$ & $57-60$ & $28.5-32$ & 30.5 & $0.93-1.15$ & $42-46$ & 21 & $24-25.5$ & $0.81-0.87$ & 2 \\
\hline Cyclustera capito & $14+14$ & 221-234 & $112-122$ & $118-125$ & $0.94-0.97$ & 173-182 & $90-93$ & $99-105$ & $0.85-0.93$ & 3 \\
\hline Cyclustera ibisae & $10+10$ & 221-240 & $141-160$ & $74-86$ & $1.73-2.09$ & 173-194 & $112-128$ & $70-80$ & $1.45-1.82$ & 4 \\
\hline Cyclustera $\mathrm{m}$ & $(4+6)+10$ & $\begin{array}{l}179-198 \\
154-163\end{array}$ & $\begin{array}{c}109-141 \\
93-109\end{array}$ & $\begin{array}{l}67-96 \\
64-70\end{array}$ & $\begin{array}{l}1.14-1.96 \\
1.43-1.70\end{array}$ & 138-147 & $90-102$ & $61-70$ & 1.33 & PD \\
\hline Cyclustera $\mathrm{cf}$. ralli & $10+10$ & $125-141$ & $75-83$ & $59-66$ & $1.20-1.35$ & 111-123 & $63-70$ & $57-66$ & $1.09-1.24$ & 3 \\
\hline Dendrouterina pilherodiae & $10+10$ & 48-49 & 19-20 & $31-33$ & $0.59-0.63$ & $40-45$ & $14.5-16$ & $26-32$ & $0.45-0.62$ & 5 \\
\hline Glossocercus auritus & $10+10$ & 242-267 & $141-165$ & $102-114$ & $1.56-1.89$ & 189-202 & $93-115$ & $83-96$ & $1.10-1.39$ & 3 \\
\hline Glossocercus caribaensis & $10+10$ & 189-211 & $106-126$ & $72-88$ & $1.20-1.73$ & $124-146$ & $66-83$ & $56-75$ & $0.97-1.29$ & 3,4 \\
\hline Glossocercus cyprinodontis & $10+10$ & 180-195 & $122-128$ & $86-93$ & $1.30-1.49$ & $129-141$ & $79-86$ & $62-74$ & $1.08-1.27$ & $3,6, \mathrm{PD}$ \\
\hline $\begin{array}{l}\text { Neogryporhynchus } \\
\text { cheilancristrotus }\end{array}$ & $10+10$ & 49-57 & $31-36$ & $18-23$ & $1.40-1.66$ & $34-40$ & $20-23.5$ & $15-18.6$ & $0.94-1.43$ & $7-9, \mathrm{PD}$ \\
\hline Paradilepis caballeroi & $12+12$ & $110-121$ & $55-59$ & $53-62$ & $0.90-1.09$ & $83-88$ & $39-41$ & $43-49$ & $0.80-0.97$ & 3 \\
\hline Paradilepis scolecina & $10+10$ & 101-115 & $55-60$ & $50-55$ & $1.12-1.23$ & 74-81 & $38-41$ & $36-39$ & $0.91-1.13$ & $8,10,11$ \\
\hline Paradilepis simoni (No. 46403) & $14+14$ & 99-102 & $44-49$ & $58-61$ & $0.72-0.83$ & $72-75$ & $31-34$ & $44-45$ & $0.71-0.78$ & PD \\
\hline (No. 38673) & $14+14$ & 103-104 & $51-53$ & $62-63$ & $0.82-0.85$ & $70-75$ & $39-40$ & $44-49$ & $0.82-0.89$ & PD \\
\hline Paradilepis rugovaginosus & $16+16$ & 93-108 & $41-53$ & $53-65$ & $0.65-0.91$ & $67-76$ & $35-41$ & $40-49$ & $0.80-0.98$ & PD \\
\hline Paradilepis cf. urceus & $10+10$ & $125-138$ & $72-83$ & $55-62$ & $1.06-1.33$ & 91-96 & $47-54$ & $46.5-50$ & $1.00-1.11$ & 3 \\
\hline Parvitaenia cochlearii & $10+10$ & $49-56.5$ & $26.5-33$ & $23-26.5$ & $1.09-1.36$ & 32-37 & $16.5-20$ & $17-18.5$ & $0.96-1.36$ & 3 \\
\hline Parvitaenia macropeos & $10+10$ & $43-46$ & $24.5-27$ & $18.5-22$ & $1.15-1.45$ & 26-30 & $12-15$ & $15-17$ & $0.71-0.89$ & 3 \\
\hline Valipora campylancristrota & $10+10$ & 23-30.5 & $9-14.5$ & $14-18.5$ & $0.60-0.91$ & $10-16.5$ & $3.5-6$ & $8-12$ & $0.34-0.56$ & $3,7,8$ \\
\hline Valipora minuta & $10+10$ & $36-40$ & $15.5-19$ & $21-24.5$ & $0.60-0.88$ & $18-21.5$ & $5.5-8.5$ & $12-15.5$ & $0.46-0.59$ & 3 \\
\hline Valipora mutabilis & $10+10$ & 28-30 & $11-13$ & $16.5-18$ & $0.60-0.76$ & $13.5-15.5$ & $4-5$ & $9-11.5$ & $0.41-0.56$ & 3 \\
\hline
\end{tabular}

*References: 1 - Bray (1974); 2 - Scholz (2001); 3 - Scholz and Salgado-Maldonado (2001); 4 - Scholz et al. (2002b); 5 - Scholz et al. (1996); 6 - Chandler (1935);

7 - Scholz (1989a); 8 - Baccarani et al. (1998); 9 - Pietrock and Scholz (2000); 10 - Scholz (1989b); 11 - Priemer and Scholz (1989); PD - present data.

${ }^{* *}$ Paratype (USNPC 46403) - adult worm from Pandion haliaetus. 


\section{TAXA OF UNCERTAIN TAXONOMIC STATUS, DOUBTFUL RECORDS AND SYNONYMS}

Amirthalingamia sp. and Cyclustera sp. of Aloo (2002)

Aloo (2002) reported metacestodes identified as Amirthalingamia sp. from the intestine of Tilapia zillii and those of the genus Cyclustera from the liver of Oreochromis leucostictus and T. zillii from Naivasha Lake in Kenya. Examination of voucher specimens from $T$. zillii provided by Aloo (2002; IPCAS C-292 and C-293) has shown their conspecificity with A. macracantha and C. magna, respectively (see Survey of species).

\section{Anomotaenia sp.}

Aderounmu and Adeniyi (1972) described and figured a metacestode, designated as Anomotaenia sp., embedded in the upper intestinal wall of Hemichromis fasciatus and Tilapia nilotica (= Oreochromis niloticus) from Nigeria. Rostellar hooks (10 only reported, unusual for this group) were $40 \mu \mathrm{m}$ long but were not illustrated.

\section{Cyclustera sp.}

Heard (1970) found adult Cyclustera cestodes in clapper rails, Rallus longirostris, from different states of the USA, and also in a red-breasted merganser and a glossy ibis from Georgia and North Carolina, respectively. According to the author, the conspecific larva occurs in the viscera of brackish water fishes Cyprinodon variegatus and Fundulus heteroclitus. However, Bona (1975), who revised Heard's material, concluded that specimens from Mergus serrator were Cyclustera ibisae and that those from clapper rails represented a different genus. It is, therefore, possible that larvae were in fact conspecific with C. ibisae or with a species of Glossocercus reported from cyprinodontiform fish, namely G. caribaensis and G. cyprinodontis (see Survey of species).

\section{Cysticercoides menidiae Chandler, 1935}

Metacestodes from Menidia menidiae described as Cysticercoides menidiae by Chandler (1935) belong in fact to Ascodilepis transfuga (Krabbe, 1869) - see Scholz (2001).

\section{Cysticercus gen. sp. of Dogiel and Bykhovskii (1938)}

Russian authors reported metacestodes ("cysticerci") from the gall bladder of Atherina boyeri (Atheriniformes: Atherinidae) and, more rarely, Caspialosa brashnikovi (= Alosa brashnikovi) (Clupeiformes: Clupeidae) and other fish from Caspian Sea. The size of the hooks (about $100 \mu \mathrm{m}$ - larger hooks, and $70 \mu \mathrm{m}-$ smaller hooks) and their shape (fig. 13) indicate the metacestodes belonged to a species of Paradilepis. However, the site of infection is not typical of larvae of this genus (see Scholz and Salgado-Maldonado 2001).

Dendrouterina papillifera (Fuhrmann, 1908) of Scholz et al. (1996)

Scholz et al. (1996) misidentified larvae of Valipora minuta (Coil, 1950) as D. papillifera (see Scholz and SalgadoMaldonado 2001; USNPC 88228). Metacestodes of the latter species from fish have not been found.

\section{Dilepididae gen. sp. 1 of Shimazu et al. (2000)}

Metacestodes from the gall bladder of Carassius auratus langsdorfii from Kami-dokanbori, Tokyo, Japan are considered to be conspecific with those of Valipora campylancristrota because of their morphology, in particular the shape and size of the rostellar hooks (about $28 \mu \mathrm{m}$ and $13 \mu \mathrm{m}$, respec- tively, as estimated from their photomicrograph - fig. 13 in Shimazu et al. 2000).

Dilepididae gen. sp. 2 of Shimazu et al. (2000)

The larvae found in the intestine of $C$. auratus langsdorfii in the Imperial Palace in Tokyo are apparently conspecific with Neogryporhynchus cheilancristrotus as indicated by their morphology, including shape (figs. 9 and 15 in Shimazu et al. 2000) and size (about $58 \mu \mathrm{m}$ and $38 \mu \mathrm{m}$, respectively, as estimated from their photomicrographs). Conspecific larvae were found in the intestine of other freshwater fish from Japan (see Survey of species).

\section{Dilepis sp.}

Under this name, metacestodes apparently belonging to several gryporhynchid genera, most probably Paradilepis Hsü, 1935 and Valipora Linton, 1927, have been reported from North American freshwater fish (see Hoffman 1999):

(i) liver of Oncorhynchus nerka (Salmoniformes: Salmonidae) from northwestern Canada and USA (Bailey and Margolis 1987);

(ii) liver and mesenteries of Lepomis gibbosus (Perciformes: Centrarchidae) from Ontario, Canada (Cone and Anderson 1977, Dechtiar and Christie 1988, Dechtiar et al. 1989);

(iii) intestinal wall of Ctenopharyngodon idella (Cypriniformes: Cyprinidae) and gall bladder of swordtail (aquarium fish) from the USA (Hoffman 1999);

(iv) intestinal wall of Notemigonus crysoleucas (Cypriniformes: Cyprinidae) from the USA (unpubl. data of Riley and R. Walker - see Hoffman 1999);

(v) wall of gall bladder of Ictalurus melas (Siluriformes: Ictaluridae) from the USA (unpubl. data of J. Warren - see Hoffman 1999);

(vi) Catostomum commersoni (Cypriniformes: Catostomidae) and Fundulus diaphanus (Atheriniformes: Cyprinodontidae), Canada (Wiles 1975, M. Wiles - unpublished data in Hoffman 1999).

The above-listed metacestodes could not be identified because their morphology had not been described and voucher specimens are not available. Nevertheless, it is apparent that they do not belong to the genus Dilepis, the adults of which do not occur in fish-eating birds (Matevosyan 1963, Schmidt 1986).

\section{Gryporhynchus sp.}

Chen Chih-leu (1973) listed metacestodes designated as Gryporhynchus sp. from Aristichthys nobilis, Carassius auratus, Cyprinus carpio, Hemiculter leucisculus, Mylopharyngodon piceus, Parabramis liaohoensis $(=P$. pekinensis $)$, and Rhinogobius giurinus from the Hupei Province, China. These larvae may be conspecific with Neogryporhynchus cheilancristrotus but voucher specimens were not available to confirm this assumption.

Chen (1984) listed larvae of Gryporhynchus (possibly Neogryporhynchus cheilancristrotus) from Ophiocephalus argus (= Channa argus), Misgurnus fossilis and Squaliobarbus curriculus.

\section{Paradilepis sp.}

Prudhoe and Hussey (1977) illustrated the metacestodes identified as Paradilepis sp. by Bray (1974 - see below).

Dechtiar et al. (1989) reported metacestodes designated as Paradilepis sp. from Lepomis gibbosus and Phoxinus neogaeus from Ontario, Canada. Comparative material of neither authors was available. 
Scholz and Salgado-Maldonado (2001) reported an unidentified species of Paradilepis from the liver of Chirostoma jordani (Atheriniformes: Atherinidae) from central Mexico (Guanajuato) (Fig. 6F). The same authors (Scholz et al. 2002a) found a conspecific adult in Phalacrocorax olivaceus from Veracruz (Mexico). This species is most probably new to science but the poor quality of the only adult specimen available did not enable them to describe this cestode formally as a new taxon.

Ezeri (2002) reported metacestodes of Paradilepis from cultured tilapia (Oreochromis niloticus) (Perciformes: Cichlidae) from Nigeria but voucher material has not been available.

\section{Parvitaenia sp.}

Wiles (1975) reported larvae of Parvitaenia sp. from the body cavity of Fundulus diaphanus (Atheriniformes: Cyprinodontidae) from Nova Scotia, Canada.

\section{Other findings}

Petrushevskii et al. (1948) found metacestodes designated as Cysticercus paradilepidis in Leuciscus idus and Tinca tinca from the $\mathrm{Ob}$ and Irtish rivers in Russia. The larvae most probably belonged to Paradilepis scolecina, the only species of Paradilepis reported from freshwater fish in Russia (Dubinina 1962, 1987).

Bray (1974) reported two species of unidentified dilepidid (= gryporhynchid) metacestodes from Tilapia nilotica (= Oreochromis niloticus) from Sudan. The larva from the intestinal lumen may have been conspecific with Parvitaenia magna Baer, 1959 (= Cyclustera magna - see above), whereas those encysted in the intestinal wall appeared to belong to Paradilepis, possibly P. delachauxi (Fuhrmann, 1909) Joyeux et Baer, 1935, thus being probably conspecific with those reported as Anomotaenia sp. (cysticercus) from O. niloticus from Nigeria (Aderounmu and Adeniyi 1972) and as dilepidid larvae from the intestinal wall of several species of tilapias (Haplochromis angustifrons, H. elegans, H. limax, H. nigripinnis, $H$. squamipinnus, $H$. wingattii, Pseudocrenilabrus multicolor, Oreochromis niloticus, T. zillii) from Uganda (Khalil and Thurston 1973).

Batra (1984) reported three metacestodes from the intestine of two tilapias (Oreochromis macrochir) from Zambia. Without having provided any information about their morphology, Batra (1984) stated they resembled metacestodes reported as "dilepidid larvae" (possibly Paradilepis delachauxi) by Khalil and Thurston (1973) from fishes in Uganda (see above).

Bailey et al. (1988) and Groot et al. (1989) reported larvae of dilepidid cestodes from Oncorhynchus nerka in British Columbia, Canada. Species attribution of these metacestodes is not clear but they may well belong to Paradilepis as metacestodes which occur in the same host from British Columbia (see Ching 1982 and Survey of species).

\section{FINAL CONCLUSIONS AND PERSPECTIVES}

The present study has shown that the existing knowledge of the diversity, host spectrum and geographical distribution of metacestodes of gryporhynchid (dilepidid) tapeworms from fish is fragmentary and considerable differences exist in the amount of data accumulated in the Holarctic Region and other parts of the world. In most gryporhynchid genera, a low proportion of taxa have been reported both as adults from fish-eating birds and metacestodes from fish (see Scholz et al. 2002a for data from Mexico where the highest number of metacestodes was found). For example, out of 20 species of Paradilepis reported as adults by Schmidt (1986), metacestodes of only 4 taxa have been reported from fish, out of 15 species of Parvitaenia, only 2 taxa are known as larvae from fish, and out of 12 species of Valipora, metacestodes of only 3 taxa have been found in fish.

The existing data also indicate that there is not a unified pattern in the degree of specificity at the level of fish intermediate host as well as site preference. Some species, such as Cyclustera capito, C. magna, Dendrouterina pilherodiae, Glossocercus cyprinodontis and Paradilepis caballeroi, have been reported from only one species of fish host, thus being classified as stenoxenous parasites. Amirthalingamia macracantha and Cyclustera ibisae occur in members of closely related genera and correspond to the oioxenous type of host specificity. On the other hand, some species, especially those reported from Europe and the Holarctic part of Asia (Neogryporhynchus cheilancristrotus, Paradilepis scolecina and Valipora campylancristrota), but also Glossocercus auritus, Parvitaenia cochlearii, Valipora minuta and $V$. mutabilis occur in a wide spectrum of fish hosts, thus exhibiting the euryxenous type of host specificity. However, further research may demonstrate that the host spectrum of most gryporhynchid metacestodes is actually wider and classification of individual species as to their host specificity will have to be changed.

Site of infection with gryporhynchid larvae differs among different genera, with most species occurring in only one microhabitat. Species of Cyclustera are confined to the mesenteries, whereas metacestodes of Glossocercus occur in the liver of fish hosts, similar to the larvae of Paradilepis. The specific site of infection with Neogryporhynchus cheilancristrotus larvae is the intestinal lumen, whereas that of metacestodes of Parvitaenia is the liver and of larvae of Valipora gall bladder.

Metacestodes of most gryporhynchid taxa have been found in freshwater fish but some, namely Ascodilepis transfuga, Cyclustera capito, C. ibisae, Glossocercus caribaensis and G. cyprinodontis, occur in brackish water fish, especially cyprinodontids from the Atlantic coast of North America (USA and Mexico), and may be limited in their occurrence to this water habitat.

The present review demonstrates that there are many missing data on the diversity, host specificity and distribution of metacestodes of gryporhynchids. It is obvious that future surveys on fish parasites should give more emphasis to searching for these larvae that may have been overlooked in previous ichthyoparasitological research. Appropriate fixation and processing of these larvae as well as their molecular characterisation seem to be necessary requirements for providing new, reliable information about this group of cestode para- 
sites. Regarding the most neglected areas, the future research should focus on the occurrence of gryporhynchid larvae in tropical Asia, Australia, South America and Africa. The actual number of gryporhynchid species occurring in fish is undoubtedly much higher than that reported until now and it is probable that larvae of numerous taxa will be reported in the near future.

Acknowledgements. Thanks are due to the following persons who provided material for this study: Peninah A. Aloo, Kenyatta University, Nairobi, Kenya; Scott Gardner, Harold W. Manter Laboratory of Parasitology, University of Nebraska, Lincoln, USA; David I. Gibson and Eileen Harris, Natural History Museum, London, UK; Mark J. Grygier, Lake
Biwa Museum, Kusatsu, Japan; Eric Hoberg and Patricia Pilitt, U.S. National Parasite Collection, Beltsville, USA; and Takeshi Shimazu, Nagano Prefectural College, Nagano, Japan. David I. Gibson, Natural History Museum, London, enabled access to the Host-Parasite Data Base. T.S. is obliged to Mr. Masayuki Kuwahara, Lake Biwa Museum, and the Momose Fishing Cooperative for providing fishes from Lake Biwa for parasitological examination during his stay at the Lake Biwa Museum in May 2001. Helpful suggestions of two anonymous referees are also acknowledged. This study was supported by the Grant Agency of the Czech Republic (project no. 524/01/ 1314 to T.S.), research project of the Institute of Parasitology, Academy of Sciences of the Czech Republic (Z6022909) and by the Lake Biwa Museum (Cooperative Research Project K0005, directed by M.J.G.).

\section{REFERENCES}

ADAMCZYK L.H. 1979: Parasitofauna of the silver crucian (Carassius auratus gibelio) from carp ponds in the Leczna - Wlodawa Lake District. Wiad. Parazytol. 25: 339-347.

ADEROUNMU E.A., ADENIYI F. 1972: Cestodes in fish from a pond at Ile-Ife, Nigeria. Afr. J. Trop. Hydrobiol. Fish. 2: 151-156.

AGAPOVA A.I. 1960: Parasites of fish in water-reservoirs of Kustanaisk Province. Trudy Instituta Zoologii, Alma Ata 12: 195-205. (In Russian).

ALI N.M., ABUL-EIS E.S., ABDUL-AMEER K.N. 1988: Study on the parasites of common carp Cyprinus carpio and other freshwater fishes in Habbaniyah Lake, Iraq. J. Biol. Sci. Res. 19: 395-407.

ALI N.M., Al-JAFERY A.R., ABDUL-AMEER K.N. 1987a: Parasitic fauna of freshwater fishes in Diyala River, Iraq. J. Biol. Sci. Res. 18: 163-181.

ALI N.M., SALIH N.E., ABDUL-AMEER K.N. 1987b: Parasitic fauna of some freshwater fishes from Tigris river, Baghdad, Iraq. III. Cestoda. J. Biol. Sci. Res. 18: 25-33.

ALOO P.A. 2002: A comparative study of helminth parasites from the fish Tilapia zillii and Oreochromis leucostictus in Lake Naivasha and Oloidien Bay, Kenya. J. Helminthol. 76: 95-102.

ANDAKOULOVA N.A. 1978: [A study of the cestode Gryporhynchus cheilancristrotus in Kazakhstan.] Trudy Vsesoyuznogo nauchno-issledovatel'skogo instituta prudovogo-rybnogo khozyaistva, Moscow, 27: 26-30. (In Russian.)

ASTACHOVA T.V., STEPANOVA G.A. 1972: [On the parasite fauna of Ctenopharyngodon idella from ponds and spawning-nursery fisheries in the Delta of the Volga.] Parazitologiya 6: 364-368. (In Russian.)

BACCARANI E.M., BONA F.V., BURIOLA E., CANESTRI TROTTI G. 1998: Larval cestode infections in tench (Tinca tinca). Parassitologia 40 (Suppl. 1): 5.

BAER J.G. 1959: Exploration des Parcs Nationaux du Congo Belge. Fasc. 1. Helminthes parasites. Inst. Parcs Nat. Congo Belge, Brussels, 163 pp.

BAER J.G., BONA F.V. 1960: Révision des Cestodes Dilepididae Fuhrm., 1907 des Ardéiformes. Note préliminaire. Boll. Ist. Mus. Zool. Univ. Torino 6: 91-143.
BAILEY R.E., MARGOLIS L. 1987: Comparison of parasite fauna of juvenile sockeye salmon (Oncorhynchus nerka) from southern British Columbia and Washington State lakes. Can. J. Zool. 65: 420-431.

BAILEY R.E., MARGOLIS L., GROOT C. 1988: Estimating stock composition of migrating juvenile Fraser River (British Columbia) sockeye salmon, Oncorhynchus nerka, using parasites as natural tags. Can. J. Fish. Aquat. Sci. 45: 586-591.

BATRA V. 1984: Prevalence of helminth parasites in three species of cichlids from a man-made lake Zambia. Zool. J. Linn. Soc. Lond. 82: 319-333.

BAUER O.N., MUSSELIUS V.A., STRELKOV Yu.A. 1981: Diseases of pond fishes. Second Edition. Light and Food Industry, Moscow, 320 pp. (In Russian.)

BAUGH S.C., SAXENA S.K. 1977: A discussion on the taxonomy of the genus Paradilepis Hsü, 1935. An. Inst. Biol., Univ. Nac. Autón. Méx., Ser. Zool. 44: 15-24.

BEVERIDGE I. 2001: The use of life cycle characters in studies of the evolution of cestodes. In: D.T.J. Littlewood and R.A. Bray (Eds.), Interrelationships of the Platyhelminthes. Systematics Association Special Volume Series 60, Taylor \& Francis, London, pp. 250-256.

BOGDANOVA E.A. 1961: The parasite fauna of some commercial species of fish in the Volga prior to the establishment of the Stalingrad reservoir. Trudy Soveshchanii ikhtiologicheskoi komissii Akademii nauk SSSR 10: 169177. (In Russian.)

BONA F.V. 1975: Etude critique et taxonomique des Dilepididae Fuhrman, 1907 (Cestoda) parasites des Ciconiiformes. Consiglio Nazionale delle Ricerche, Roma, 750 pp.

BONA F.V. 1983a: Variability and growth of cestodes: premises to a biometric analysis. Dendrouterina pilherodiae meridionalis n. subsp., parasite of Egretta alba (Ciconiiformes) in Argentina and redescription of the type of $D$. pilherodiae Mahon, 1956 (Cestoda, Dilepididae). Part I. Riv. Parassitol. 44: 280-297.

BONA F.V. 1983b: Variability and growth of cestodes: premises to a biometric analysis, Dendrouterina pilherodiae meridionalis n. subsp., parasite of Egretta alba (Ciconiiformes) in Argentina and redescription of the type of $D$. 
pilherodiae Mahon, 1956 (Cestoda, Dilepididae). Part II. Riv. Parassitol. 44: 427-469.

BONA F.V. 1994: Family Dilepididae Railliet \& Henry, 1909. In: L.F. Khalil, A. Jones and R.A. Bray (Eds.), Keys to the Cestode Parasites of Vertebrates. CAB International, Wallingford, Oxon, UK, pp. 445-554.

BOUTORINA T.E., ERMOLENKO A.V. 2001: Parasitofauna of the Amur catfish (Parasilurus asotus L.) of the Lake Khanka basin. Bull. Eur. Assoc. Fish Pathol. 21: 154-156.

BRAY R.A. 1974: A new genus of dilepidid cestode in Tilapia nilotica (L., 1758) and Phalacrocorax carbo (L., 1758 ) in Sudan. J. Nat. Hist. 8: 589-596.

CHANDLER A.C. 1935: Parasites of fishes in Galveston Bay. Proc. U.S. Natl. Mus. 83: 55-61.

CHEN CHIH-LEU (Ed.) 1973: [An illustrated guide to the fish disease and causative pathogenic fauna and flora in the Hupei Province.] Science Press (for Institute of Hydrobiology, Academia Sinica), Peking, 456 pp. (In Chinese.)

CHEN Y.-S. 1984: The parasitic cestodes of fishes from Liao $\mathrm{He}$ in China. In: Parasitic organisms of fresh-water fish of China (compiled by Institute of Hydrobiology Academia Sinica). Agricultural Publishing House, Beijing, pp. 160 176. (In Chinese, with English summary in separate volume, pp. 27-28).

CHERNOVA T.N., MAMYSHEV I.G., SPIRANTI N.O. 1988: Parasite fauna in Tkibul reservoir. In: I. Abdurakhmanovich, Abdusalyamov and O.N. Bauer (Eds.), Bolezni i Parazity v Teplovodnom Rybnom Khozyaistve. Izdatel'stvo Donish, Dushanbe, pp. 180-182. (In Russian, with English summary.)

CHERVY L. 2002: The terminology of larval cestodes or metacestodes. Syst. Parasitol. 52: 1-33.

CHING H.L. 1982: Report of the metacestode of Paradilepis simoni Rausch, 1949 (Cyclophyllidea, Dilepidae) from fish in British Columbia. Can. J. Zool. 60: 184-186.

CHUBB J.C. 1980: Seasonal occurrence of helminths in freshwater fishes. Part III. Larval Cestoda and Nematoda. Adv. Parasitol. 18: 1-120.

CHUBB J.C., POOL D.W., VELTKAMP C.J. 1987: A key to the species of cestodes (tapeworms) parasitic in British and Irish freshwater fishes. J. Fish Biol. 31: 517-543.

COIL W.H. 1950: The genus Ophiovalipora Hsü, 1935 (Cestoda: Dilepididae) with the description of Ophiovalipora minuta sp. nov. from the green heron (Butorides virescens L.). J. Parasitol. 36: 55-61.

COIL W.H. 1955a: The morphology of Cyclustera capito (Rudolphi, 1819) Fuhrmann, 1901. Trans. Am. Microsc. Soc. 74: 353-357.

COIL W.H. 1955b: Parvitaenia cochlearii sp. nov. (Cestoda: Dilepididae) a new tapeworm parasitic in boat-billed heron, Cochlearius cochlearius. Proc. Helminthol. Soc. Wash. 22: 66-68.

CONE D.K., ANDERSON R.C. 1977: Parasites of pumpkinseed (Lepomis gibbosus L.) from Ryan Lake, Algonquin Park, Ontario. Can. J. Zool. 55: 1410-1423.

DAVIS J., HUFFMAN D.G. 1975: The ecology of the helminth parasites of Gambusia affinis and Gambusia geiseri (Osteichthyes: Poeciliidae) from the area of San
Marcos, Texas. Aquat. Stn. Southwest Tex. State Univ., San Marcos, Res. Rep. No. 75-1, 161 pp.

DECHTIAR A.O., CHRISTIE W.J. 1988: Survey of the parasite fauna of Lake Ontario fishes, 1961-1971. In: S.J. Nepszy (Ed.), Parasites of Fishes in the Canadian Waters of the Great Lakes. Technical Report. Great Lakes Fishery Commission, No. 51: 66-95.

DECHTIAR A.O., MacLEAN J.A., NEPSZY S.J. 1989: Parasites of fishes from Algonquin Park lakes. Ontario Fisheries Technical Report Series. Toronto, No. 29, 19 pp.

del HOYO J., ELLIOTT A., SARGATAL J. (Eds.) 1992: Handbook of the Birds of the World. Vol. 1. Lynx Edicions, Barcelona, $696 \mathrm{pp}$.

DÍAZ-UNGRÍA C. 1968: Identificación de una colección de parásitos de vertebrados venezolanos. Bol. Soc. Venez. Cienc. Nat. 27: 525-536.

DOGIEL V.A., BYKHOVSKII B.E. 1938: [Parasites of fish of the Caspic Sea.] Trudy kompleksnogo izucheniya Kaspiiskogo morya 7. Publ. House Acad. Sci. USSR, Moscow, 179 pp. (In Russian.)

DUBININ V.B. 1952: [Fauna of helminth larvae of vertebrates of the River Volga Delta.] Parazitol. sb., Leningrad 14: 213-226. (In Russian.)

DUBININA M.N. 1962: Class tapeworms Cestoidea Rud., 1808. In: B.E. Bychovskii (Ed.), Keys to the Parasites of Freshwater Fish of the USSR. Izd. Akad. Nauk USSR, Moscow - Leningrad, pp. 384-438. (In Russian.)

DUBININA M.N. 1971: Cestodes from fishes of the River Amur basin. Parazitol. sb., Leningrad 25: 77-119. (In Russian.)

DUBININA M.N. 1987: Class Cestoda Rudolphi, 1808. In: O.N. Bauer (Ed.), Keys to the Parasites of Freshwater Fish of the USSR. Second Edition. Volume 3, Part 2. Nauka, Leningrad, pp. 5-76. (In Russian.)

DUPONT F., CRIVELLI A.J. 1988: Do parasites confer a disadvantage to hybrids? A case study of Alburnus alburnus $\times$ Rutilus rubilio, a natural hybrid of Lake Mikri Prespa, Northern Greece. Oecologia, Berlin 75: 587-592.

DZHALILOV U.D. 1985: Parasite fauna of fishes from Lake Yashilkul (Pamirs). In: O.N. Bauer et al. (Eds.), VIIIth All-Union Congress on Parasites and Diseases of Fishes. Astrakhan. Izdatel'stvo Nauka, Leningrad. Abstracts of Papers, pp. 44-45. (In Russian.)

ERGENS R. 1969: The suitability of ammonium picrateglycerin in preparing slides of lower Monogenoidea. Folia Parasitol. 16: 320.

ERGENS R., GUSSEV V.A., IZYUMOVA N.A., MOLNÁR K. 1975: Parasite fauna of fishes of the Tisa river basin. Rozpravy ČSAV, řada matemat. a přírod. věd, Academia, Praha, 85: $117 \mathrm{pp}$.

ERMOLENKO A.V., BUTORINA T.E. 1998: Parasite fauna of carp fishes of the subfamily Cultrinae in the Khanka Lake Basin. Parazitol. sb., Leningrad 32: 156-166. (In Russian.)

ESINENKO-MARITS N.M. 1965: Cestodes of fish of reservoirs of Moldavian SSR. Parazity Zhiv. Rast. 1: 26. (In Russian.)

EZERI G.N.O. 2002: Infection by larval cestodes of the genus Paradilepis in cultured Oreochromis niloticus (L.). J. Aquat. Sci. 17: 60-62. 
FEDYNICH A.M., PENCE D.B., BERGAN J.F. 1997: Helminth community structure and pattern in sympatric populations of double-crested and neotropic cormorants. J. Helminthol. Soc. Wash. 64: 176-182.

FREEMAN R.S. 1954: Paradilepis rugovaginosus n. sp. (Cestoda: Dilepididae) from the osprey, with notes on the genus Oligorchis Fuhrmann, 1906. J. Parasitol. 40: 22-28.

FROESE R., PAULY D. (Eds.) 2003: FishBase. World Wide Web electronic publication. www.fishbase.org (29 August 2003).

FUHRMANN O. 1908: Die Cestoden der Vögel. Zool. Jahrb. 10, Suppl., $232 \mathrm{pp}$.

FUHRMANN O. 1909: Die Cestoden der Vögel des weissen Nils. In: L.A. Jägerskiöld (Ed.), Results of the Swedish zoological expedition to Egypt and the White Nile, 1901, 3: pp. 1-53.

GAVRILOVA N.G., KARIMOV S.B. 1989: On the changes in the parasite fauna of fishes of the Kairakkum water reservoir for many years. Parazitologiya 23: 250-256. (In Russian, with English summary.)

GOLIKOVA M.N. 1960: [Ecological parasitological studies of biocenoses of some lakes in the Kaliningrad Region.] III. Parasite fauna of fishes. Vestnik Leningradskogo universiteta, Seriya Biologiya 9: 110-121. (In Russian.)

GRABDA-KAZUBSKA B., BATURO-WARSZAWSKA B., POJMAŃSKA T. 1987: Dynamics of parasite infestation of fish in Lakes Dgal Wielki and Warniak in connection with introduction of phytophagous species. Acta Parasitol. Pol. 32: 1-28.

GROOT C., BAILEY R.E., MARGOLIS L., COOKE K. 1989: Migratory patterns of sockeye salmon (Oncorhynchus nerka) smolts in the Strait of Georgia, British Columbia, as determined by analysis of parasite assemblages. Can. J. Zool. 67: 1670-1678.

GRUPCHEVA G., NEDEVA I. 1999: Parasite fauna of the crucian carp (Carassius auratus gibelio Bloch) in the Zrebchevo reservoir (Bulgaria). Acta Zool. Bulg. 51: 115122. (In Bulgarian.)

HANZELOVÁ V., RYŠAVÝ B. 1999: Synopsis of cestodes in Slovakia V. Dilepididae, Dipylidiidae and Paruterinidae. Helminthologia 36: 111-117.

HEARD R.W. 1970: Parasites of the clapper rail, Rallus longirostris Boddaert. II. Trematodes and cestodes from Spartina marshes of the eastern United States. Proc. Helminthol. Soc. Wash. 37: 147-153.

HIROSE H., MANO N., SHIMADA M. 1999: Parasites of aquatic animals and water quality in an urban reservoir. Suisan Zoshoku 47: 427-430.

HOBERG E.P., JONES A., BRAY R.A. 1999: Phylogenetic analysis among the families of the Cyclophyllidea (Eucestoda) based on comparative morphology, with new hypotheses for co-evolution in vertebrates. Syst. Parasitol. 42: 51-73.

HOBERG E.P., MARIAUX J., BROOKS D.R. 2001: Phylogeny among orders of the Eucestoda (Cercomeromorphae): integrating morphology, molecules and total evidence. In: D.T.J. Littlewood and R.A. Bray (Eds.), Interrelationships of the Platyhelminthes. The Systematics Association Special Volume Series 60. Taylor \& Francis, London, pp. 112-126.
HOFFMAN G.L. 1999: Parasites of North American Freshwater Fishes. Second Edition. University of California Press, Berkeley, Los Angeles, London, 486 pp.

HUEY R., DRONEN N.O. Jr. 1981: Nematode and cestode parasites from the roseate spoonbill, Ajaia ajaja, including Paradilepis diminuta sp. n. (Cestoda: Dilepididae). J. Parasitol. 67: 721-723.

IBRAGIMOV S.R. 1988: Parasitofauna of fishes of Turkmen Gulf of the Caspian Sea. Izvestiya Akademii nauk Turkmenskoi SSR, Ashkhabad 2: 51-56. (In Russian, with English summary.)

ISKOV M.P. 1965: Parasites of Abramis brama and Carassius auratus from the Vasilev fish-breeding farm on the Kakhov water reservoir. Problemy parazitologii. Trudy Ukrainskogo respublikanskogo nauchnogo obshchestva parazitologov 4: 220-225. (In Russian.)

IVASIK V.M. 1953: Carp parasites and the diseases they cause in fish farms in the western districts of the Ukrainian S.S.R. Trudy Nauchno-issledovatel'skogo instituta prudovogo i ozernogo rechnogo rybnogo khozyaistva Ukrainskoi SSR 9: 85-122. (In Russian.)

IZYUMOVA N.A. 1977: Parasitic fauna of reservoir fishes of the USSR and its evolution. Nauka, Leningrad, 284 pp. (In Russian.)

JARA Z., OLECH W. 1964a: Dynamika inwazji Cysticercus dilepidis campylancistrotae (Aubert) u karpi hodowanych (Cyprinus carpio L.). Wiad. Parazytol. 10: 518-520.

JARA Z., OLECH W. 1964b: Zmiany w jelicie karpi (Cyprinus carpio L.) spowodowane obecnością Cysticercus dilepidis campylancistrotae (Aubert). Wiad. Parazytol. 10: 521-522.

JARECKA L. 1970a: Life cycle of Valipora campylancristrota (Wedl, 1855) Baer and Bona 1958-1960 (Cestoda - Dilepididae) and the description of cercoscolex - a new type of cestode larva. Bull. Acad. Pol. Sci., Classe II 28: 99-102.

JARECKA L. 1970b: On the life cycles of Paradilepis scolecina (Rud., 1819) Hsü, 1935, and Neogryporhynchus cheilancristrotus (Wedl, 1855) Baer and Bona, 1958-1960 (Cestoda - Dilepididae). Bull. Acad. Pol. Sci., Classe II 15: 159-163.

JARECKA L. 1975: Ontogeny and evolution of cestodes. Acta Parasitol. Pol. 23: 93-114.

JENSEN L.A., SCHMIDT G.D., KUNTZ R.E. 1983: A survey of cestodes from Borneo, Palawan, and Taiwan, with special reference to the new species. Proc. Helminthol. Soc. Wash. 50: 117-134.

JOYEUX C., BAER J.G. 1935: Notices helminthologiques. Bull. Soc. Zool. Fr. 60: 482-501.

KAKACHEVA-AVRAMOVA D. 1983: Helminths of Freshwater Fishes in Bulgaria. Publ. House of the Bulgarian Academy of Sciences, Sofia, 262 pp. (In Bulgarian.)

KALBE M., WEGNER K.M. REUSCH T.B.H. 2002: Dispersion patterns of parasites in $0+$ year three-spined sticklebacks: a cross population comparison. J. Fish Biol. 60: 1529-1542.

KARSTAD L., SILEO L., OKECH G., KHALIL L.F. 1982: Pathology of Paradilepis scolecina (Cestoda: Dilepididae) in the white-necked cormorant (Phalacrocorax carbo). J. Wildl. Dis. 18: 507-509. 
KAŽIĆ D.M. 1970: Endohelminti Ekonomski Najznacajnijih Riba Skadarskogo Jezera. Institute of Biology, Titograd, $128 \mathrm{pp}$.

KAZIEVA N.S. 1981: The dynamics of invasion of fishes with cestodes in the Varbarinsk reservoir. In: S.O. Movsesyan (Ed.), Abstracts of the Second Zakavkazsk Conference on Parasitology, Erevan, 1979. Akademiya Nauk Armyanskoi SSR, Erevan, pp. 114-115. (In Russian.)

KAZIEVA N.S., MIKAILOV T.K. 1990: Helminth fauna's dependence on the feeding of fishes in Varvara water reservoir. In: T.K. Mikailov (Ed.), The Investigations in Helminthology in Azerbaijan. ELM, Baku, pp. 105-110. (In Russian.)

KENNEDY C.R. 1974: A checklist of British and Irish freshwater fish parasites with notes on their distribution. J. Fish Biol. 6: 613-644.

KHALIL L.F., THURSTON J.P. 1973: Studies on the helminth parasites of freshwater fishes of Uganda including the descriptions of two new species of digeneans. Rev. Zool. Bot. Afr. 87: 209-248.

KINSELLA J.M., COLE R.A., FORRESTER D.J., RODERICK C.L. 1996: Helminth parasites of the osprey, Pandion haliaetus, in North America. J. Helminthol. Soc. Wash. 63: 262-265.

KINSELLA J.M., FORRESTER D.J. 1999: Parasitic helminths of the common loon, Gavia immer, on its wintering grounds in Florida. J. Helminthol. Soc. Wash. 66: $1-6$.

KIRICHENKO L.M. 1996: On the epizootic situation in suburban fishery farms of Tambov. In: A.N. Alekseev et al. (Eds.), Parasitological Problems of the Megapolis. Meeting of the Parasitological Society of the Russian Academy of Sciences. Zoological Institute, RAS, St Petersburg, pp. 45-46. (In Russian.)

KIRIN D.A. 2001: Biodiversity of the helminth communities of Leuciscus cephalus and Alburnus alburnus from Kardzhali reservoir. Dokl. Balgar. Akad. Naukite 54: 9598. (In Bulgarian.)

KISKAROLY M., IBROVIĆ M., DZUVIĆ A., OBRATIL S. 1981: A contribution to the study of parasitofauna of the marshland birds of cyprinid fisheries in Bosnia-Hercegovina and their role in the epizootiology of ichthyoparasitoses. Veterinaria (Sarajevo) 30: 291-303.

KNEZEVIĆ B., KAZIĆ D., NEDIĆ D., KAVARIĆ M. IVANOVIĆ B. 1978: Unique characteristics of ichthyofauna and icthyoparasites of Skadar Lake. Int. Ver. Theor. Angew. Limnol. Verh. 20: 2166-2171.

KOMAROVA M.S. 1957: Seasonal parasitofauna dynamics of the tench in the Donets River. Zool. Zh. 36: 654-657. (In Russian.)

KÖRTING W. 1984: Larval cyclophyllidean cestodes in carp and tench. Bull. Eur. Assoc. Fish Pathol. 4: 40-41.

KOZICKA J. 1971: Cestode larvae of the family Dilepididae Fuhrmann, 1907 parasitizing fresh-water fish in Poland. Acta Parasitol. Pol. 19: 85-93.

KULAKOVSKAYA O.P. 1965: A study of fish parasites in the Dunai Delta. Raboty po parazitofaune yugo-zapada SSSR. Inst. Zool. Akad. Nauk Moldavskoi SSR, Kishinev, pp. 84-86. (In Russian.)
KULAKOVSKAYA O.P. 1969: Cestodes of freshwater fish of the Ukrainian SSR. Summary (Avtoreferat) of D.Sc. thesis. Academy of Sciences of Ukrainian SSR, Kiev, 45 pp. (In Russian.)

KULAKOVSKAYA O.P., KOVAL B.P. 1973: Parasite Fauna of Fish of the Danube River Basin. Naukova Dumka, Kiev, 212 pp. (In Russian.)

KURASHVILI B.E., MIKAILOV T.K., GOGEBASHVILI I.V. 1980: Parasitofauna of fishes in the basin of the River Kura within the USSR. Metsniereba, Tbilisi, 258 pp. (In Russian.)

MAHON J. 1955: Contributions to the genus Paradilepis Hsü, 1935. Parasitology 45: 63-78.

MAHON J. 1956: Dendrouterina pilherodiae sp. nov. (Dilepididae) from Pilherodius pileatus (Bodd.). Can. J. Zool. 34: 28-34.

MALMBERG G. 1957: Om förekomsten av Gyrodactylus på svenska fiskar. Särtryck ur Skrifter utgivna av Södra Sveriges Fiskeriförening, Årsskrift 1956, 19-76.

MARGARITOV N.M. 1976: Parasites and diseases of the carp in state fish-cultural farms of Bolgaria [sic]. Izvestiya Gosudarstvennogo nauchno-issledovatel'skogo instituta ozernogo i rechnogo rybnogo khozyaistva 105: 40-42. (In Russian.)

MARGARITOV N. 1992: Species composition of the parasites of common carp bred in fish ponds and cages in Bulgaria. Godishnik na Sofiiskiya Universitet St Kliment Okhridski, Biologicheski Fakultet 81: 60-73. (In Bulgarian, with English summary.)

MARIAUX J. 1998: A molecular phylogeny of the Eucestoda. J. Parasitol. 84: 114-124.

MATEVOSYAN E.M. 1963: Dilepidoidea - tapeworm helminths of domestic and wild animals. Essentials of Cestodology, Volume 3. Publ. House of the Acad. Sci. of the USSR, Moscow, 688 pp. (In Russian).

McLAUGHLIN J.D. 1974: A redescription of Paradilepis longivaginosus (Mayhew, 1925) (Cestoda: Dilepididae) and a comparison with Paradilepis simoni Rausch, 1949 and Paradilepis rugovaginosus Freeman, 1954. Can. J. Zool. 52: 1185-1190.

MHAISEN F.T., KHAMEES N.R. 1995: Check-list of the parasites and disease agents of the Siluriformes of Iraq. Zoology in the Middle East, Heidelberg 11: 113-120.

MIKAILOV T.K 1975: Parasites of Fish of Water Bodies of Azerbaidzhan (Systematics, Dynamics, Distribution). Publ. House ELM, Baku, 300 pp. (In Russian.)

MIKAILOV T.K., IBRAGIMOV S.R. 1980: Ecology and zoogeography of fish parasites of the Lenkoran district. Izdatel'stvo Elm, Baku, 115 pp. (In Russian.)

MOLNÁR K. 1970: Beiträge zur Kenntnis der Fischparasitenfauna Ungarns VI. Cestoda, Nematoda, Acanthocephala, Hirudinea. Parasitol. Hung. 3: 51-76.

MOLNÁR K., HANEK G., FERNANDO C.H. 1974: Parasites of fishes from Laurel Creek, Ontario. J. Fish Biol. 6: 717728.

MOLNÁR K., SZÉKELY C. 1996: Parasitological survey of some important fish species of Lake Balaton. Parasitol. Hung. 28: 63-82. 
MORAVEC F. 1983: Occurrence of endoparasitic helminths in carp (Cyprinus carpio) from the Mácha lake fishpond system. Acta Soc. Bohemoslov. Zool. 48: 261-278.

MORAVEC F. 1985: Occurrence of the endoparasitic helminths in tench (Tinca tinca) from the Mácha lake fishpond system. Acta Soc. Bohemoslov. Zool. 49: 32-50.

MORAVEC F. 1986: Occurrence of endohelminths in three species of cyprinids (Abramis brama, Rutilus rutilus and Scardinius erythrophthalmus) of the Mácha lake fishpond system, Czechoslovakia. Acta Soc. Bohemoslov. Zool. 50: 49-69.

MORAVEC F. 2001: Checklist of the Metazoan Parasites of Fishes of the Czech Republic and the Slovak Republic (1873-2000). Academia, Prague, 168 pp.

MURAI É., MOLNÁR K., GUBÁNYI A. 1997: Occurrence of the adult and plerocercus forms of Paradilepis scolecina (Rudolphi, 1819) (Cestoda: Dilepididae) in Lake Balaton, Hungary. Parasitol. Hung. 29-30: 33-38.

NAIMOVA A.M., ROITMAN V.A. 1989: Parasitic diseases of reared fishes and their prophylaxis. Itogi Nauki $\mathrm{i}$ Techniki. Seriya Zooparazitologiya, Moscow 10: 208 pp. (In Russian.)

NIEMCZUK W., CHORBINSKI P. 1996: Localization and activity of some hydrolases in the larvae of tapeworms Neogryporhynchus cheilancristrotus and Triaenophorus nodulosus parasitizing in fish. Wiad. Parazytol. 42: 415420.

NIKULINA A.N. 1985: Treatment of Valipora in carp and some nematological indices of the fish. Byull. Vses. Inst. Eksp. Vet. 57: 54-55. (In Russian.)

OLSEN O.W. 1939: The cysticercoid of the tapeworm Dendrouterina nycticoracis Olsen, 1937 (Dilepididae). Proc. Helminthol. Soc. Wash. 6: 20-21.

OSMANOV S.O. 1971: Parasites of fish of Uzbekistan. Izdatel'stvo Filiala AN Uzbekskoi SSR, Tashkent, 532 pp. (In Russian.)

PETRUSHEVSKII G.K., MOSEVICH M.V., SHCHUPAKOV I.G. 1948: Parasite fauna of fishes of the Rivers Ob and Irtish. Izvestiya Vsesoyuznogo nauchno-issledovatel'skogo instituta ozernogo i rechnogo rybnogo khozyaistva 27: 67-97. (In Russian.)

PASTUSZKO J., JASTRZEBSKI M., KLOCZEWSKA M. 1984: Rola chwastu rybiego w rozprzestrzenianiu inwazji pasozytniczych w karpiowych gospodarstwach stawowych. Wiad. Parazytol. 30: 223-227.

PICHELIN S., CRIBB T.H., BONA F.V. 1998: Glossocercus chelodinae (MacCallum, 1921) n. comb. (Cestoda: Dilepididae) from freshwater turtles in Australia and a redefinition of the genus Bancroftiella Johnston, 1911. Syst. Parasitol. 39: 165-181.

PIETROCK M., SCHOLZ T. 2000: Morphometry and seasonal occurrence of metacestodes of Neogryporhynchus cheilancristrotus (Cyclophyllidea: Dilepididae) in the blue bream (Abramis ballerus) from the Oder River (Germany/Poland). Folia Parasitol. 47: 181-185.

POJMAŃSKA T. 1991: Pasożyty ryb Polski (klucze do oznaczania). Tasiemce - Cestoda. Institut Parazytologii im. W. Stefańskiego, Polska Akademia Nauk, Warszawa, 135 pp.

POPIOLEK M. 2002: Helminth parasites of the weatherfish Misgurnus fossilis (L.) (Cobitidae, Pisces) from tributaries of the middle Odra River basin (SW Poland). Helminthologia 39: 179.

PRIEMER J., SCHOLZ T. 1989: Larvae of Dilepididae (Cestoda) in Cyprinus carpio from the DDR. Angew. Parasitol. 30: 27-30.

PRUDHOE S., HUSSEY C.G. 1977: Some parasitic worms in freshwater fishes and fish-predators from the Transvaal, South Africa. Zool. Afr. 12: 113-147.

RAUSCH R. 1949: Paradilepis simoni n. sp., a cestode parasitic in the osprey (Cestoda: Dilepididae). Zoologica (N.Y.) 34: 1-3.

RAUSCH R. 1955: Cyclustera ardae n. sp. and the status of Dendrouterina Fuhrmann, 1912 (Cestoda: Dilepididae). Proc. Helminthol. Soc. Wash. 22: 25-29.

RAUTSKIS E. 1988: Parasites of Fish of Lithuania. Mokslas, Vilnius, 208 pp. (In Russian.)

RAZMASHKIN D.A. 1984: Parasite fauna and diseases of grass carp at lake fish farms of Tyumen District. Sbornik nauchnykh trudov Gosudarstvennogo nauchno-issledovatel'skogo instituta ozernogo i rechnogo rybnogo khozyaistva 226: 50-55. (In Russian.)

RAZMASHKIN D.A. 1990: Diseases and parasites of fish in commercial lake fisheries of western Siberia. In: O.N. Bauer and N.M. Pronin (Eds.), Parasites and Diseases of Hydrobionts from the Arctic Sea Province. Nauka, Sibirskoe otdelenie, Novosibirsk, pp. 15-31. (In Russian.)

REGO A.A., CHUBB J.C., PAVANELLI G.C. 1999: Cestodes in South American freshwater teleost fishes: keys to genera and brief description of species. Rev. Bras. Zool. 16: 299-367.

ROLBIECKI L., ROKICKI, J., MOROZIŃSKA-GOGOL J., CHIBANI M. 1999: Larval stages of helminths in fish from the Vistula Lagoon and the Gulf of Gdańsk in relation to bird occurrence. Bull. Sea Fish. Inst. 2: 51-60.

RYSAVY B., MACKO J.K. 1973: Bird cestodes of Cuba I. Cestodes of birds of the orders Podicipediformes, Pelecaniformes and Ciconiiformes. An. Inst. Biol. Univ. Nac. Autón. Méx., Ser. Zool. 42:1-28.

RYZHIKOV K.M., RYŠAVÝ B., KHOKHLOVA I.G. TOLKATCHEVA L.M., KORNYUSHIN V.V. 1985: Helminths of Fish-eating Birds of the Palaearctic Region II. Cestoda and Acanthocephales. Academia, Prague, 412 pp.

SAFONOV N.N., VASILKOV G.V. 1971: Distribution of cysticercosis among cyprinid fishes. Byulleten Vsesoyuznogo trudogo krasnogo znameni instituta gelmintologii im. K.I. Skryabina 5: 95-96. (In Russian.)

SALGADO-MALDONADO G., CABAÑAS-CARRANZA G., CASPETA-MANDUJANO J.M., SOTO-GALERA E., MAYÉN-PEÑA E., BRAILOVSKY D., BÁEZ-VALÉ R. 2001: Helminth parasites of freshwater fishes of the Balsas River drainage basin of southwestern Mexico. Comp. Parasitol. 68: 196-203.

SAPOZHNIKOV G.I. 1975: Dilepis unilateralis in carp. In: VII Nauchnaya konferentsiya parazitologov Ukrainy, September 1975, Donetsk. Abstracts of papers, pp. 132135. (In Russian; cited after Chubb 1980.)

SAPOZHNIKOV G.I., SKVORTSOVA F.K., LADUKHIN A.I. 1974: Dilepidosis of carp. Veterinariya, Moscow 6: 73-74. (In Russian.) 
SAXENA S.K. 1968: A restudy of Parvitaenia campylancristrota (Wedl, 1855) n. comb. with a note on the taxonomy of the genus Parvitaenia Burt, 1940. Zool. Anz. 183: 284-291.

SCHMIDT G.D. 1986: CRC Handbook of Tapeworm Identification. CRC Press, Boca Raton, Florida, USA, 675 pp.

SCHMIDT G.D., BUSH A.O. 1972: Parvitaenia ibisae sp. n. (Cestoidea: Dilepididae), from birds in Florida. J. Parasitol. 58: 1096-1097.

SCHMIDT G.D., COURTNEY C.H. 1973: Parvitaenia heardi sp. n. (Cestoidea: Dilepididae) from the great blue heron, Ardea herodias, in South Carolina. J. Parasitol. 59: 821823.

SCHMIDT G.D., NEILAND K.A. 1971: Helminth fauna of Nicaragua. VI. Sacciuterina mathevossiani sp. nov. (Dilepididae) and other cestodes of birds. Parasitology 62: 145-149.

SCHOLZ T. 1989a: Amphilinida and Cestoda, parasites of fish in Czechoslovakia. Acta Sci. Nat. Brno 23: 1-56.

SCHOLZ T. 1989b: First record of the larva of Paradilepis scolecina (Rudolphi, 1819) (Cyclophyllidea: Dilepididae) in fishes from Czechoslovakia. Folia Parasitol. 36: 65-66.

SCHOLZ T. 2001: Identity of Cysticercoides menidiae Chandler, 1935 (Cestoda: Dilepididae). J. Parasitol. 87: 927-928.

SCHOLZ T., ERGENS R. 1990: Cestodes of fishes from Mongolia. Acta Soc. Zool. Bohemoslov. 54: 287-304.

SCHOLZ T., KUCHTA R., SALGADO-MALDONADO G. 2002a: Cestodes of the family Dilepididae (Cestoda: Cyclophyllidea) from fish-eating birds in Mexico: a survey of species. Syst. Parasitol. 52: 171-182.

SCHOLZ T., SALGADO-MALDONADO G. 2001: Metacestodes of the family Dilepididae (Cestoda: Cyclophyllidea) parasitising fishes in Mexico. Syst. Parasitol. 49: $23-40$.

SCHOLZ T., STEELE E., BECKHAM M., BRAY R.A 2002b: Larval tapeworms (Cestoda: Dilepididae) from the mummichog Fundulus heteroclitus (Linnaeus, 1766) and striped killifish Fundulus majalis (Walbaum, 1792) from South Carolina, USA Comp. Parasitol. 69: 104-108.

SCHOLZ T., VARGAS-VÁZQUEZ J., MORAVEC F., VIVAS-RODRÍGUEZ C., MENDOZA-FRANCO E. 1996: Cestoda and Acanthocephala of fishes from cenotes (= sinkholes) of Yucatan, Mexico. Folia Parasitol. 43: 141-152.

SEPÚLVEDA M.S., SPALDING M.G., KINSELLA J.M., BJORK R.D., McLAUGHLIN G.S. 1994: Helminths of the roseate spoonbill, Ajaia ajaja, in southern Florida. J. Helminthol. Soc. Wash. 61: 179-189.

SEPÚLVEDA M.S., SPALDING M.G., KINSELLA J.M., FORRESTER D.J. 1999: Parasites of the great egret (Ardea albus) in Florida and a review of the helminths reported for the species. J. Helminthol. Soc. Wash. 66: 713.

SHIMAZU T., KURAMOCHI T., ARAKI J., MACHIDA M. 2000: Digenean, cestode, and nematode parasites of freshwater fishes of the Imperial Palace, Tokyo. Mem. Natl. Sci. Mus., Tokyo 35: 211-231.

SKRYABINA E.S. 1974: Helminths of Acipenserid Fish (Acipenseridae Bonaparte, 1831). Nauka, Moscow, 168 pp. (In Russian.)

SKVORTSOVA F.K. 1979: Valipora infection in carp. Veterinariya, Moscow 3: 54-56. (In Russian.)

SKVORTSOVA F.K., KOZACHENKO N.T., NIKULINA A.N. 1985: Ultrastructural changes in the tegument of fish cestodes caused by anthelmintics. Veterinariya, Moscow 7: 40-42. (In Russian)

SPASSKAYA L.P., SPASSKII A.A., IVAKINA E.M. 1974: Cestodes of Ardea cinerea in Moldavia. Parazity zhivotnykh i rastenii 10: 51-66. (In Russian.)

SPASSKY A.A. 1995: Changes in the type of symmetry in higher cestodes ontogeny. Doklady biologicheskii nauk 343: 571-573. (In Russian.)

SPASSKY A.A., SPASSKAYA L.P. 1973: New subfamily Gryporhynchinae, subfam. n. (Cestoda: Dilepididae). Izv. Akad. Nauk Mold. SSR. 9: 56-59. (In Russian.)

SUVOROV A.V. 1981: Testing of some anthelmintics against Valipora infection in pond fish. Byull. Vses. Inst. Eksp. Vet. 41: 24-24.

STUDNICKA M., STANKIEWICZ E.B., SIWICKI A., KLOCZEWSKA M. 1984: Treatment of Valipora campylancristrota in carp. Gospodarka Rybna 36: 16-17. (In Polish.)

SYSOLYATINA-ANDAKULOVA N.A. 1979: The life cycle of the cestode Dilepis unilateralis. Parazity i bolezni ryb, Moscow, 23: 135-148. (In Russian.)

TAKEMOTO R.M., PAVANELLI G.C., BONA F. 1994: Ocorrência de larvas de Valipora sp. (Cestoda: Cyclophyllidea) em Prochilodus scrofa, „curimba“, peixe de escama do rio Paraná, região de Porto Rico, Pr, Brasil. VIII Simpósio Brasileiro de Aqüicultura, Piracicaba, p. 170 (cited after Rego et al. 1999).

UNDERWOOD H.T., DRONEN N.O. 1986: Neocyclustera ralli gen. et sp. n. (Cestoidea: Dilepididae) and other endohelminths from clapper rails, Rallus longirostris, from a marsh in Galveston County, Texas. Proc. Helminthol. Soc. Wash. 53: 59-62.

VIDAL-MARTÍNEZ V.M., AGUIRRE-MACEDO M.L., SCHOLZ T., GONZÁLEZ-SOLÍS D., MENDOZAFRANCO E.F. 2001. Atlas of the Helminth Parasites of Cichlid Fish of Mexico. Academia, Prague, 166 pp.

WEDL C. 1855: Charakteristik mehrerer gröstenteils neuer Taenien. Sitzungsber. Kaiser. Akad. Wiss. Wien, Math. Naturwiss. 18: 2-27.

WILES M. 1975: Parasites of Fundulus diaphanus (LeSueur) (Pisces: Cyprinodontidae) in certain Nova Scotian freshwaters. Can. J. Zool. 53: 1578-1580.

YAMAGUTI S. 1940: Studies on the helminth fauna of Japan. Part 30. Cestodes of birds, II. Jpn. J. Med. Sci. 1: 175211.

Accepted 18 March 2004 
Appendix 1. Host-Parasite List. Name of fish according to FishBase (Froese and Pauly 2003).

Acipenseriformes: Acipenseridae (3 fish species infected with 3 gryporhynchid species)

Acipenser nudiventris - Paradilepis scolecina, Valipora campylancristrota

Acipenser stellatus - Valipora campylancristrota

Pseudoscaphirhynchus kaufmanni-Neogryporhynchus cheilancristrotus, Paradilepis scolecina, Valipora campylancristrota

Atheriniformes: Atherinidae (5/5)

Atherinella crystallina-Parvitaenia cochlearii

Chirostoma humboldtianum - Valipora campylancristrota

Chirostoma jordani - Paradilepis caballeroi, Paradilepis cf. urceus, Valipora campylancristrota

Chirostoma riojai - Valipora campylancristrota

Menidia menidia-Ascodilepis transfuga

Characiformes: Characidae (1/1)

Astyanax fasciatus - Glossocercus auritus

Characiformes: Prochilodontidae (1/1)

Prochilodus lineatus - Valipora campylancristrota

Clupeiformes: Clupeidae (2/2)

Alosa caspia - Valipora campylancristrota

Alosa kessleri-Neogryporhynchus cheilancristrotus

Cypriniformes: Cobitidae (3/1)

Cobitis taenia - Neogryporhynchus cheilancristrotus

Misgurnus anguillicaudatus - Neogryporhynchus

cheilancristrotus

Misgurnus fossilis - Neogryporhynchus cheilancristrotus

Cypriniformes: Cyprinidae (45/5)

Abramis ballerus - Neogryporhynchus cheilancristrotus

Abramis bjoerkna - Neogryporhynchus cheilancristrotus,

Paradilepis scolecina

Abramis brama - Neogryporhynchus cheilancristrotus,

Paradilepis scolecina, Valipora campylancristrota

Abramis sapa - Neogryporhynchus cheilancristrotus

Alburnoides taeniatus - Neogryporhynchus cheilancristrotus,

Valipora campylancristrota

Alburnus albidus - Paradilepis scolecina

Alburnus alburnus - Neogryporhynchus cheilancristrotus,

Paradilepis scolecina, Valipora campylancristrota

Aristichthys nobilis - Paradilepis scolecina, Valipora campylancristrota

Aspiolucius esocinus - Neogryporhynchus cheilancristrotus

Aspius aspius - Neogryporhynchus cheilancristrotus,

Paradilepis scolecina, Valipora campylancristrota

Barbus brachycephalus - Neogryporhynchus

cheilancristrotus, Paradilepis scolecina, Valipora campylancristrota

Barbus capito - Neogryporhynchus cheilancristrotus, Paradilepis scolecina, Valipora campylancristrota

Capoeta capoeta - Neogryporhynchus cheilancristrotus, Paradilepis scolecina

Capoetobrama kuschakewitschi-Neogryporhynchus cheilancristrotus

Carassius auratus - Neogryporhynchus cheilancristrotus, Paradilepis scolecina, Valipora campylancristrota

Carassius carassius - Neogryporhynchus cheilancristrotus, Paradilepis scolecina, Valipora campylancristrota
Chalcalburnus chalcoides - Neogryporhynchus cheilancristrotus, Paradilepis scolecina, Valipora campylancristrota

Chondrostoma cyri-Paradilepis scolecina

Chondrostoma nasus - Paradilepis scolecina

Ctenopharyngodon idella-Neogryporhynchus cheilancristrotus, Valipora campylancristrota

Culter alburnus - Paradilepis scolecina

Cyprinus carpio - Cyclustera cf. ralli, Neogryporhynchus cheilancristrotus, Paradilepis scolecina, Valipora campylancristrota

Gnathopogon caerulescens - Neogryporhynchus cheilancristrotus

Gnathopogon elongatus - Paradilepis scolecina

Hemiculter eigenmanni - Valipora campylancristrota

Hemiculter leucisculus - Paradilepis scolecina

Hypophthalmichthys molitrix - Valipora campylancristrota

Leuciscus cephalus - Neogryporhynchus cheilancristrotus, Valipora campylancristrota

Leuciscus idus - Neogryporhynchus cheilancristrotus, Paradilepis scolecina

Leuciscus lehmanni - Neogryporhynchus cheilancristrotus

Leucaspius delineatus - Neogryporhynchus cheilancristrotus, Valipora campylancristrota

Notropis sallei-Cyclustera cf. ralli

Oreoleuciscus humilis - Paradilepis scolecina

Oreoleuciscus potanini-Paradilepis scolecina

Pelecus cultratus - Neogryporhynchus cheilancristrotus,

Paradilepis scolecina, Valipora campylancristrota

Ptychocheilus oregonensis - Paradilepis simoni (?)

Rhodeus sericeus - Neogryporhynchus cheilancristrotus, Paradilepis scolecina, Valipora campylancristrota

Rutilus rutilus - Neogryporhynchus cheilancristrotus, Paradilepis scolecina, Valipora campylancristrota

Scardinius erythrophthalmus - Neogryporhynchus cheilancristrotus, Paradilepis scolecina, Valipora campylancristrota

Schizopygopsis stoliczkae - Paradilepis scolecina

Schizothorax intermedius - Neogryporhynchus cheilancristrotus, Valipora campylancristrota

Tinca tinca - Neogryporhynchus cheilancristrotus, Paradilepis scolecina, Valipora campylancristrota

Tribolodon hakonensis - Paradilepis scolecina

Varicorhinus sp. - Paradilepis scolecina

Zacco platypus - Neogryporhynchus cheilancristrotus

Cyprinodontiformes: Cyprinodontidae (2/2)

Cyprinodon variegatus variegatus - Glossocercus cyprinodontis

Floridichthys polyommus - Cyclustera capito

Cyprinodontiformes: Goodeidae (3/2)

Alloophorus robustus - Cyclustera cf. ralli

Girardinichthys multiradiatus - Cyclustera cf. ralli, Valipora campylancristrota

Xenotoca variata - Cyclustera cf. ralli

Cyprinodontiformes: Fundulidae (4/2)

Fundulus grandissimus - Glossocercus caribaensis

Fundulus heteroclitus - Cyclustera ibisae, Glossocercus caribaensis

Fundulus majalis - Cyclustera ibisae, Glossocercus caribaensis

Fundulus persimilis - Glossocercus caribaensis 
Cyprinodontiformes: Poeciliidae (6/3)

Gambusia affinis - Valipora minuta

Poecilia catemaconis - Glossocercus auritus

Poecilia mexicana-Glossocercus auritus

Poecilia sphenops - Glossocercus auritus, Valipora minuta

Poecilia sp. - Glossocercus auritus

Poeciliopsis gracilis - Glossocercus auritus, Parvitaenia cochlearii

Esociformes: Esocidae (1/3)

Esox lucius - Neogryporhynchus cheilancristrotus, Paradilepis scolecina, Valipora campylancristrota

Gasterosteiformes: Gasterosteidae (3/2)

Gasterosteus aculeatus - Paradilepis scolecina,Valipora campylancristrota

Pungitius platygaster - Paradilepis scolecina

Pungitius pungitius - Paradilepis scolecina

Perciformes: Blenniidae (1/1)

Salaria fluviatilis - Valipora campylancristrota

Perciformes: Centrarchidae (2/1)

Micropterus punctatus - Valipora minuta

Micropterus salmoides - Valipora minuta

Perciformes: Channidae (1/1)

Channa argus - Neogryporhynchus cheilancristrotus

Perciformes: Cichlidae (8/7)

Cichlasoma beani - Valipora mutabilis

Cichlasoma callolepis - Paradilepis caballeroi

Cichlasoma geddesi - Valipora mutabilis

Cichlasoma istlanum - Parvitaenia macropeos

Cichlasoma urophthalmus - Glossocercus caribaensis

Oreochromis niloticus - Amirthalingamia macracantha

Thorichthys meeki-Valipora mutabilis

Tilapia zillii-Amirthalingamia macracantha, Cyclustera magna

Perciformes: Eleotridae (2/1)

Dormitator latifrons - Parvitaenia cochlearii

Gobiomorus maculatus - Parvitaenia cochlearii
Perciformes: Gobiidae (1/1)

Neogobius melanostomus - Paradilepis scolecina

Perciformes: Mugilidae (2/2)

Agonostomus monticola - Parvitaenia cochlearii

Liza abu-Neogryporhynchus cheilancristrotus

Perciformes: Percidae (5/3)

Gymnocephalus cernuus - Neogryporhynchus

cheilancristrotus, Paradilepis scolecina

Perca fluviatilis - Neogryporhynchus cheilancristrotus,

Paradilepis scolecina, Valipora campylancristrota

Perca schrenki - Neogryporhynchus cheilancristrotus

Sander lucioperca - Valipora campylancristrota

Zingel streber-Neogryporhynchus cheilancristrotus

Salmoniformes: Salmonidae (3/2)

Oncorhynchus mykiss - Paradilepis rugovaginosus

Oncorhynchus nerka-Paradilepis rugovaginosus,

Paradilepis simoni

Prosopium williamsoni-Paradilepis rugovaginosus

Scorpaeniformes: Cottidae (1/1)

Cottus asper - Paradilepis simoni (?)

Siluriformes: Bagridae (1/1)

Mystus pelusius - Valipora campylancristrota

Siluriformes: Heptapteridae (1/4)

Rhamdia guatemalensis - Dendrouterina pilherodiae,

Valipora campylancristrota, Valipora minuta, Valipora

mutabilis

Siluriformes: Ictaluridae (1/1)

Ictalurus melas - Valipora mutabilis

Siluriformes: Siluridae $(2 / 3)$

Silurus glanis - Neogryporhynchus cheilancristrotus,

Paradilepis scolecina, Valipora campylancristrota

Silurus asotus - Neogryporhynchus cheilancristrotus 